\title{
\|ARTYKULY
}

Przeglad SejMOWY

nr 5(160)/2020, s. 9-34; https://doi.org/10.31268/PS.2020.63

KATARZYNA GRZELAK-BACH*

KAROL KARSKI**

\section{Rola polskiego parlamentu w systemie organów wdrażających wyroki Europejskiego Trybunału Praw Czlowieka}

W opracowaniu przedstawiono wybrane zagadnienia związane z rola parlamentu krajowego we wdrażaniu i wykonywaniu orzeczeń Europejskiego Trybunału Praw Człowieka. Ukazano specyfikę krajowego procesu stanowienia prawa jako systemu legislacji ad hoc, która w niewielkim stopniu stanowi reakcję na zobowiązania międzynarodowe w dziedzinie praw człowieka. Podjęto również próbę zbadania wpływu dorobku orzeczniczego Trybunału na krajowy system prawny poprzez analizę kolejnych etapów procesu legislacyjnego. Uwypuklono rolę Komitetu Ministrów Rady Europy, którego zadaniem jest zabezpieczenie tego, by państwa nie pomijały — swoimi działaniami lub zaniechaniami - skutków wyroków. W opracowaniu podjęto próbę oceny stopnia uwrażliwienia i podnoszenia świadomości na temat znaczenia standardów Konwencji o ochronie praw człowieka i podstawowych wolności w krajowych instytucjach oraz organach władzy ustawodawczej i wykonawczej, które aktywnie ze sobą współdziałają. Realizowanie wytycznych prawidłowej legislacji w kontekście praw człowieka to takie działanie podmiotów uczestniczących w procesie stanowienia prawa, które uwzględniając normy prawa krajowego oraz międzynarodowego, w sposób szczególny kształtują sytuację indywidualną jednostki, jak i ogółu podmiotów. Parlamenty mogą rozliczać władzę wykonawczą z realizacji zobowiązań za pomocą różnych instrumentów, stąd też wiele zagadnień prawnych, które były przedmiotem rozstrzygnięć Europejskiego Trybunału Praw Człowieka, wpłynęło w sposób znaczący na refleksję legislacyjną i podjęcie odpowiednich działań prawodawczych w kierunku zbliżenia ustawodawstwa polskiego do standardu konwencyjnego. Na Sejmie i Senacie spoczywa ogromna odpowiedzialność za jakość stanowionego prawa, na etapie parlamentarnym rola Rady Ministrów staje się mniej wiodąca, lecz nie wykluczona. To właśnie stanowi o niezwykłej wadze dialogu pomiędzy władzą wykonawczą a ustawodawczą, który powinien w sposób konstruktywny finalizować wizję przepisów bliżej praw człowieka.

SŁowa KLUCzowe: parlament, prawa człowieka, legislacja, prawo krajowe, Konstytucja RP, zobowiązania prawnomiędzynarodowe, implementacja, Europejski Trybunał Praw Człowieka

\section{The role of the Polish Parliament in the system of bodies implementing judgments of the European Court of Human Rights}

The study presents selected issues related to the role of the national parliament in the implementation and execution of judgments of the European Court of Human Rights (ECHR). It presents the specificity of the national law-making process as a system of ad hoc legislation, 
which to a small extent is a response to international obligations in the field of human rights. The study also attempts to examine the impact of the case law of the ECHR on the national legal system by analyzing the subsequent stages of the legislative process. It emphasizes the role of the Committee of Ministers of the Council of Europe, whose task is to ensure that states do not overlook - by their actions or omissions - the effects of judgments. The study attempts to assess the degree of sensitisation and the increase of awareness regarding the significance of the standards of the Convention for the Protection of Human Rights and Fundamental Freedoms (Convention) in the national institutions and executive and legislative authorities that actively cooperate with each other. The implementation of the guidelines of correct legislation in the context of human rights is an activity of entities involved in the law-making process which, taking into account the standards of national and international law, shape in a specific manner the situation of individuals as well as of all entities. Parliaments can hold the executive authorities accountable for the execution of obligations by means of various instruments, and thus many legal issues that were the subject of the judgments of the ECHR had significant impact on the legislative process and the undertaking of respective legislative actions towards bringing Polish legislation closer to the standards of the Convention. The Sejm (the Polish Lower House) and the Senate bear enormous responsibility for the quality of the adopted law; at the parliamentary stage the role of the Council of Ministers of the Republic of Poland becomes less leading, but not excluded. This is what determines the unique role of the dialogue between the executive and legislative authorities, which should finalize the vision of the legal regulations closer to human rights in a constructive manner.

KEY wORDs: parliament, human rights, legislation, national law, Constitution of the Republic of Poland, international legal obligations, implementation, European Court of Human Rights

* Dr Katarzyna Grzelak-Bach, Uniwersytet Kardynała Stefana Wyszyńskiego w Warszawie, Wydział Prawa i Administracji, adiunkt w Katedrze Ochrony Praw Człowieka i Prawa Międzynarodowego Humanitarnego, k.grzelak-bach@uksw.edu.pl, https://orcid.org/0000-0002-8598-0591

** Dr hab. Karol Karski, profesor Uniwersytetu Warszawskiego, Wydział Prawa i Administracji, kierownik Zakładu Prawa Międzynarodowego Publicznego, k.karski@wpia.uw.edu.pl,https://orcid.org/0000-0003-0757-6283

\section{Wprowadzenie}

Realizowanie zobowiązań prawnomiędzynarodowych nierozerwalnie łączy się z aktywnym prowadzeniem polityki zagranicznej ${ }^{1}$. Są w to zaangażowane wszystkie podmioty trójpodziału: władza ustawodawcza, władza wykonawcza i władza sądownicza.

1 K. Gałka, Zasada przestrzegania prawa międzynarodowego jako zasada konstytucyjna (art. 9 Konstytucji RP), [w:] Polskie prawo stosunków międzynarodowych. Zagadnienia wybrane, red. C. Mik, Ł. Kułaga, Toruń 2018, s. 95-121; L. Mażewski, Prowadzenie polityki zagranicznej w Rzeczypospolitej Polskiej, „Ruch Prawniczy, Ekonomiczny i Socjologiczny” 2009, nr 3, s. 9; I. Wrońska, Pozycja ustrojowa władzy wykonawczej $w$ Polsce $w$ aspekcie wykonywania wyroków Europejskiego Trybunału Praw Człowieka - wybrane zagadnienia, „Białostockie Studia Prawnicze” 2016, t. 20/B, s. 205. 
Konstytucja RP powierza działania w zakresie prowadzenia polityki zagranicznej wyłącznie organom władzy wykonawczej: Radzie Ministrów i Prezydentowi Rzeczypospolitej Polskiej ${ }^{2}$. Jednak tylko rząd ma przypisaną wprost kompetencję ,prowadzenia polityki zagranicznej”. Sejm i Senat mogą działać w tym zakresie (na płaszczyźnie prawnomiędzynarodowej) jedynie pośrednio ${ }^{3}$. Parlamenty nie są bowiem organami reprezentującymi państwa w stosunkach zewnętrznych. To domena władzy wykonawczej. Występowanie parlamentu w relacjach zewnętrznych, jako całości lub którejkolwiek $\mathrm{z}$ jego izb, nie jest działaniem podejmowanym $\mathrm{w}$ imieniu państwa, tj. w charakterze organu reprezentującego państwo w obrocie prawnomiędzynarodowym. O ile ma ono miejsce, a niekiedy mówimy o dyplomacji parlamentarnej, można je traktować wyłącznie $w$ charakterze działania danego organu w imieniu własnym ${ }^{4}$.

Prawo międzynarodowe wymaga od państw wywiązywania się z zaciągniętych zobowiązań. Muszą one tak ukształtować stan faktyczny i prawny, aby zobowiązania te mogły być przestrzegane i wykonywane. Państwo nie może powoływać się na niedostatki swojego prawa wewnętrznego w celu uchylenia się od wykonania swoich obowiązków wynikających z prawa międzynarodowego ${ }^{5}$. Z perspektywy zobowiązań konwencyjnych jest

${ }^{2}$ Art. 133 oraz art. 146 Konstytucji Rzeczypospolitej Polskiej z dnia 2 kwietnia 1997 r., Dz.U. nr 97, poz. 483 , ze zm.

${ }^{3}$ L. Garlicki, Polskie prawo konstytucyjne. Zarys wykładu, Warszawa 2001, s. 303-307; Polskie prawo konstytucyjne, red. W. Skrzydło, Lublin 2006, s. 342-354; A. Sylwestrzak, Władza rządzaca, władza opozycja i władza neutralna na tle tradycyjnych teorii podzialu władz, [w:] Wokót wybranych problemów konstytucjonalizmu. Księga jubileuszowa Profesora Andrzeja Bałabana, red. J. Ciapała, P. Mijal, Warszawa 2017, s. $320-335$.

${ }^{4}$ Od tej reguły możliwe są odstępstwa, gdy umowa międzynarodowa - w formule wyjątku — ustanawia w konkretnym zakresie odmienne rozwiązanie. Przykładowo członkami Zgromadzenia Parlamentarnego Rady Europy [dalej: ZPRE] są parlamentarzyści krajowi delegowani, co do zasady, przez parlamenty krajowe, których w art. 25 i 26 Statutu Rady Europy (Statut Rady Europy, przyjęty w Londynie dnia 5 maja 1949 r., ETS No. 001, Dz.U. z 1994 r. nr 118, poz. 565 i 566) określono mianem ,przedstawicieli członka”, tj. państwa członkowskiego. Delegacja do ZPRE jest wspólna dla całego parlamentu, także jak w przypadku Polski — dwuizbowego. Członków polskiej delegacji oraz ich zastępców wskazują kluby parlamentarne zgodnie z decyzją prezydiów obu izb o rozdziale miejsc. Liczba delegatów przynależnych danemu państwu w ZPRE jest określona w art. 26 Statutu Rady Europy. Polska delegacja do ZPRE składa się z 12 przedstawicieli oraz ich 12 zastępców, tj. 3 senatorów i 3 ich zastępców oraz 9 posłów i 9 ich zastępców. Przewodnik senatora. Kontakty międzyparlamentarne, Warszawa 2019, s. 6. Tak umocowani parlamentarzyści w przeciwieństwie do rządu nie mają generalnej kompetencji do reprezentowania państwa w stosunkach zewnętrznych, a zakres ich uprawnień w relacjach na forum Rady Europy jest określony w jej statucie, czyli w umowie międzynarodowej, oraz uszczegółowiony w wydanych na jego podstawie lub w celu jego wykonania aktach prawa wewnętrznego tej organizacji międzynarodowej. Bycie przedstawicielem państwa nie oznacza w tym przypadku posiadania prawa do składania oświadczeń, w tym zaciągania zobowiązań w imieniu państwa, lecz jest formułą mianowania członków organu międzynarodowego, którzy swoje uprawnienia realizują zasadniczo w formule współkształtowania stanowisk tego organu. Na temat statusu parlamentu krajowego oraz jego członków w relacjach prawnomiędzynarodowych vide szerzej K. Karski, Parlament, [w:] Wielka encyklopedia prawa, red. B. Hołyst, R. Hauser, t. 4: Międzynarodowe prawo publiczne, red. J. Symonides, D. Pyć, Warszawa 2014, s. 348-349.

5 J. Barcik, T. Srogosz, Prawo międzynarodowe publiczne, wyd. 3, Warszawa 2017, s. 75-108; R. Bierzanek, J. Symonides, Prawo międzynarodowe publiczne, wyd. 8, Warszawa 2004, s. 26-28; W. Czapliński, A. Wyrozumska, Prawo międzynarodowe publiczne. Zagadnienia systemowe, wyd. 3, Warszawa 2004, 
bez znaczenia, który z organów państwa strony Konwencji o ochronie praw człowieka i podstawowych wolności ${ }^{6}$ [dalej: Konwencja, EKPC] wykona wyrok Europejskiego Trybunału Praw Człowieka [dalej: Trybunał, ETPC]. Wewnętrzne uwarunkowania ustrojowe jednoznacznie dowodzą jednak, co podkreśla Michał Balcerzak, że w Polsce podmiotem odgrywającym najistotniejszą rolę w tym zakresie, w szczególności w zakresie monitoringu, koordynacji i inicjowania konkretnych czynności, jest Rada Ministrów zgodnie z treścią art. 146 ust. 1-2, ust. 4 pkt 9 Konstytucji RP ${ }^{7}$. Sejm powinien w szczególności wspierać i kontrolować prace rządu , dbając o to, aby wykonywanie wyroków Trybunału było sprawnie realizowane w ramach kompetencji własnych administracji rządowej’. Jak słusznie stwierdza Piotr Radziewicz: „Sejm powinien brać czynny udział w wykonywaniu wyroków ETPC i aktywnie przyczyniać się do prawidłowego funkcjonowania konwencyjnego systemu ochrony praw człowieka w Polsce. Należy jednak zastrzec, że pozycja ustrojowa organów władzy ustawodawczej limituje środki oddziaływania Sejmu i zakres jego potencjalnych obowiązków, jakie może skutecznie realizować, nie naruszając zasady podziału władzy w demokratycznym państwie prawnym. Szczególną powściągliwość trzeba zachować zwłaszcza wobec tych podmiotów, którym przysługuje konstytucyjny status niezależności i niezawisłości (np. sądy), wyłączający kształtowanie wzajemnych relacji z Sejmem na zasadach właściwych dla tzw. funkcji kontrolnej władzy ustawodawczej. Silniejsze środki wpływu mogą natomiast zostać zastosowane wobec wszelkich agend administracji rządowej"10.

Wielowymiarowość krajowego procesu legislacyjnego ${ }^{11}$ wynika głównie $\mathrm{z}$ faktu udziału różnych podmiotów posiadających inicjatywę ustawodawczą oraz ze względu na jego wyjątkową złożoność ${ }^{12}$. Etap rządowy ${ }^{13}$ to udział wielu wyspecjalizowanych instytucji czuwających nad prawidłowością wdrażania norm prawa międzynarodowego.

s. 514-585; W. Góralczyk, S. Sawicki, Prawo międzynarodowe publiczne w zarysie, wyd. 16, Warszawa 2015, s. 32-35; R. Kwiecień, Transformacja umów międzynarodowych jako forma stanowienia prawa w państwie (z uwzględnieniem praktyki polskiej), „Państwo i Prawo” 1997, z. 4, s. 3-15.

${ }^{6}$ ETS No. 005, ze zm., Dz.U. z 1993 r. nr 61, poz. 284, ze zm.

${ }^{7}$ M. Balcerzak, Analiza prawna na temat wykonywania wyroków Europejskiego Trybunatu Praw Człowieka przez Sejm, [w:] Wykonywanie wyroków Europejskiego Trybunału Praw Człowieka przez Sejm, Warszawa 2012, s. 2. Confer A. Ciżyńska, J. Karakulski, K. Kos, J. Pyłko, Prawo konstytucyjne wraz z orzecznictwem Trybunatu Konstytucyjnego, Warszawa 2017, s. 216-219.

${ }^{8}$ M. Balcerzak, Analiza prawna...; D. Górecki, Polskie prawo konstytucyjne, Warszawa 2012.

9 M. Balcerzak, Analiza prawna...; A. Bodnar, Wykonywanie orzeczeń Europejskiego Trybunału Praw Człowieka w Polsce. Wymiar instytucjonalny, Warszawa 2018, s. 51-56.

${ }^{10}$ P. Radziewicz, Rekomendacje dotyczace wykonywania wyroków Europejskiego Trybunatu Praw Człowieka przez Sejm, [w:] Wykonywanie wyroków Europejskiego Trybunału Praw Człowieka przez Sejm, Warszawa 2012, s. 2.

${ }^{11}$ H. Rot, Wartości proceduralne tworzenia prawa. Studium legislacji porównawczej, Wrocław 1992, s. 23.

12 A. Bodnar, D. Pudzianowska, Uwzględnianie Europejskiej Konwencji Praw Człowieka w procesie legislacyjnym, [w:] Rola orzecznictwa w systemie prawnym, Warszawa 2015, s. 103-110.

13 Ustawa z dnia 8 sierpnia 1996 r. o Radzie Ministrów, Dz.U. z 2019 r. poz. 1171; uchwała nr 190 Rady Ministrów z dnia 29 października 2013 r. Regulamin pracy Rady Ministrów, M.P. z 2016 r. poz. 1006 i 1204, z 2018 r. poz. 114 i 278 oraz z 2019 r. poz. 137. 
To m.in. Rządowe Centrum Legislacji ${ }^{14}$, Rada Legislacyjna ${ }^{15}$ oraz Centrum Analiz Strategicznych ${ }^{16}$. W toku prac parlamentarnych procedowane są przedłożenia nie tylko rządowe, gdyż trybom legislacyjnym podlegają także projekty obywatelskie, poselskie, senackie oraz prezydenckie ${ }^{17}$. Projekty te są szczegółowo analizowane oraz opracowywane w komisjach parlamentarnych ${ }^{18}$, w których aktywnie uczestniczą eksperci ${ }^{19}$ oraz legislatorzy $^{20}$, ale również przedstawiciele np. Rzecznika Praw Obywatelskich [dalej: RPO] ${ }^{21}$ czy Prokuratorii Generalnej RP22, sygnalizując w przedłożeniach ryzyko doprowadzenia do roszczeń odszkodowawczych, mankamenty w obszarze prawa konstytucyjnego, prawa Unii Europejskiej (UE) czy też międzynarodowego prawa z zakresu praw człowieka ${ }^{23}$.

${ }^{14}$ Rządowe Centrum Legislacji zapewnia koordynację działalności legislacyjnej Rady Ministrów, Prezesa Rady Ministrów i innych organów administracji rządowej oraz obsługę prawną Rady Ministrów. Rządowe Centrum Legislacji, <https://www.rcl.gov.pl/>, dostęp 18 II 2020.

${ }_{15}$ Rada Legislacyjna jest organem opiniodawczo-doradczym Prezesa Rady Ministrów i Rady Ministrów istniejącym od 1972 r. Rada Legislacyjna wydaje opinie o ważniejszych rządowych projektach ustaw. Czyni to na wniosek: Prezesa Rady Ministrów, przewodniczącego stałego komitetu Rady Ministrów, Szefa Kancelarii Prezesa Rady Ministrów, Prezesa Rządowego Centrum Legislacji lub Sekretarza Rady Ministrów. Skład Rady Legislacyjnej dobierany jest według klucza kompetencji w wyodrębnionych obszarach prawa (prawo cywilne, prawo karne, prawo administracyjne, prawo międzynarodowe itd.), jednakże należy zauważyć, że obszar praw człowieka jest zawsze reprezentowany. Rada Legislacyjna, $<$ https://radalegislacyjna.gov.pl/>, dostęp 18 II 2020.

${ }^{16}$ Centrum Analiz Strategicznych jest organem pomocniczym Prezesa Rady Ministrów, który przygotowuje projekty strategii z zakresu polityki publicznej oraz opiniuje projekty zgłaszane do wykazu prac legislacyjnych i programowych rządu.

${ }_{17}$ Tworzenie prawa jest traktowane głównie jako wyrażenie woli prawodawcy, którego intencje nie zawsze będą zbieżne ze standardem konwencyjnym, zatem często kluczową rolę sygnalizacyjną będą odgrywać służby legislacyjne czy to Rządowego Centrum Legislacji, czy też biur legislacyjnych Kancelarii Sejmu i Senatu - confer P. Skuczyński, Etyka legislatora a racjonalne tworzenie prawa, [w:] Leges ab omnibus intellegi debent. Ksiega XV-lecia Rzadowego Centrum Legislacji, red. W. Brzozowski, A. Krzywoń, Warszawa 2015, s. 442-461.

${ }^{18}$ Przebieg posiedzeń komisji parlamentarnych jest publicznie dostępny: Petne zapisy posiedzeń komisji sejmowych, Sejm RP, <https://www.sejm.gov.pl/Sejm8.nsf/biuletyny.xsp>, dostęp 18 II 2020, oraz Komisje senackie, Senat RP, <https://www.senat.gov.pl/prace/komisje-senackie/>, dostęp 18 II 2020.

19 S. Wronkowska, Ekspert a proces tworzenia prawa, „Państwo i Prawo” 2000, nr 9, s. 5; P. Radziewicz, Doradztwo naukowe w pracach Sejmu, „Przegląd Sejmowy” 2013, nr 5(118), s. 33-50.

${ }^{20}$ R. Iłowiecki, Status legislatora w organach wtadzy publicznej. Zawód legislator, „Przegląd Sejmowy" 2010, nr 6(101), s. 35.

${ }^{21}$ Do kompetencji RPO należy m.in. składanie stanowisk oraz opinii na etapie prac parlamentarnych, a także udział przedstawiciela Biura RPO w posiedzeniach komisji sejmowych i senackich. Rzecznik Praw Obywatelskich, $<$ https://www.rpo.gov.pl/pl/content/interwencje-w-sprawie-zmiany-przepisow>, dostęp 18 II 2020.

${ }_{22}$ Do kompetencji Prokuratorii Generalnej RP należy m.in. wydawanie opinii o projektach aktów normatywnych dotyczących istotnych praw i interesów Rzeczypospolitej Polskiej oraz przygotowywanie na wniosek Prezesa Rady Ministrów raportów, analiz i stanowisk obejmujących zagadnienia prawne dotyczące w szczególności projektów aktów normatywnych. Prokuratoria Generalna Rzeczypospolitej Polskiej, <https://prokuratoria.gov.pl/kompetencje-prokuratorii,m,m1,33>, dostęp 18 II 2020.

${ }_{23}$ J. Szymanek, Udziat czynnika eksperckiego w procesie ustawodawczym, [w:] Leges ab omnibus intellegi debent. Księga XV-lecia Rządowego Centrum Legislacji, red. W. Brzozowski, A. Krzywoń, Warszawa 2015, s. 419-441. 
Można rozważyć, czy swego rodzaju specyfiką krajowego procesu stanowienia prawa jest funkcjonowanie systemu legislacji ad hoc ${ }^{24}$, która najczęściej jest działaniem legislacyjnym realizującym osiągnięcie określonego politycznie rezultatu bądź wynika z obowiązku transponowania prawa UE, rzadziej zaś stanowi reakcję na zobowiązania międzynarodowe w dziedzinie praw człowieka.

\section{Standard do osiągnięcia}

Konwencja ustanowiła Trybunał dla osób poszukujących ochrony praw człowieka w Europie ${ }^{25}$. Od momentu uznania jurysdykcji organów strasburskich (1 maja 1993 r.) polscy obywatele mogą składać skargi do Trybunału, zaś: „Wraz ze wzrostem liczby państw-stron i gwałtownym zwiększeniem spraw rozpatrywanych powstała kwestia skutecznego egzekwowania orzeczeń ETPC"26.

Przestrzeganie przez państwa zobowiązań prawnomiędzynarodowych wynikających z Konwencji odbywa się na dwóch płaszczyznach ${ }^{27}$. Trzeba przy tym pamiętać, że państwa, poddając się jurysdykcji Europejskiego Trybunału Praw Człowieka, nie doceniały stopnia, w jakim EKPC oraz dorobek orzeczniczy Trybunału wpłyną na ich krajowe systemy prawne ${ }^{28}$. Pierwszą bowiem konsekwencją związania się Konwencją jest wprowadzanie w systemie prawa wewnętrznego odpowiednich standardów poszanowania praw i wolności jednostki, unormowanych w tym traktacie, zaś drugą jest obowiązek wykonywania orzeczeń Europejskiego Trybunału Praw Człowieka w sytuacji stwierdzenia naruszenia Konwencji przez pozwane państwo ${ }^{29}$. System ochrony podstawowych praw i wolności ustanowiony przez Konwencję jest oparty na zasadzie subsydiarności ${ }^{30}$. Zapewnienie jego stosowania należy przede wszystkim do państw

${ }^{24}$ A. Jasiak, Constitutional Constraints on Ad Hoc Legislation. A Comparative Study of the United States. Germany and the Netherlands, Cambridge-Antwerp-Maastricht 2011, s. 5.

${ }_{25}$ T. Jasudowicz, J. Bartosiewicz, R. Fordoński, Orzecznictwo Europejskiego Trybunału Praw Człowieka w sprawach polskich, Olsztyn 2012, s. 7-9.

${ }^{26}$ R. Kropiwnicki, System wykonywania wyroków Europejskiego Trybunału Praw Człowieka w Polsce, [w:] Aktualne wyzwania ochrony wolności i praw jednostki, red. M. Jabłoński, S. Jarosz-Żukowska, Wrocław 2014, s. 301. Vide także T. Barkhuysen, M. Van Emmerik, A Comparative View on the Execution of the Judgments of the European Court of Human Rights, [w:] European Court of Human Rights: Remedies and Execution of Judgments, red. T.A. Christou, J.P. Raymond, London 2005, s. 3; R. Kropiwnicki, Instytucjonalizacja standardów Rady Europy na przyktadzie polskiej skargi na przewlektość postępowań sadowych i prokuratorskich, [w:] Nowe wyzwania i rozwiazania w europejskim systemie praw człowieka, red. J. Jaskiernia, K. Spryszak, Toruń 2018, s. 165-176.

${ }^{27}$ W. Brzozowski, A. Krzywoń, M. Wiącek, Prawa czlowieka, Warszawa 2018, s. 85-86.

${ }^{28} \mathrm{H}$. Keller, A. Stone Sweet, Assessing the Impact of the ECHR on National Legal Systems, [w:] A Europe of Rights: The Impact of the ECHR on National Legal Systems, red. H. Keller, A. Stone Sweet, Oxford 2008, s. 678.

${ }^{29}$ M. Balcerzak, Odpowiedzialność państwa strony Europejskiej konwencji o ochronie praw człowieka i podstawowych wolności. Studium prawnomiędzynarodowe, Toruń 2013; I. Wrońska, op. cit., s. 203.

${ }^{30}$ M.A. Nowicki, Wokót Konwencji Europejskiej. Komentarz do Europejskiej Konwencji Praw Człowieka, Warszawa 2009, s. 19-24. 
stron Konwencji, natomiast organ sądowy stojący na straży postanowień Konwencji, tj. ETPC, powinien interweniować jedynie wtedy, gdy państwo nie wywiąże się ze swoich zobowiązań ${ }^{31}$.

Orzeczenie ETPC, w którym Trybunał stwierdza naruszenie przez państwo Konwencji, jest tylko zakończeniem pewnego etapu, który otwiera kolejny, nie mniej istotny dla dalszych relacji obu stron sporu (państwa naruszyciela i jednostki, która naruszenia doznała) - etap wykonania orzeczenia Trybunału, czyli jego wdrożenia przez władze krajowe $^{32}$. Art. 46 ust. 2 Konwencji stanowi, że nadzór nad wykonywaniem wyroków Trybunału sprawuje Komitet Ministrów Rady Europy ${ }^{33}$. Zadanie to Komitet Ministrów realizuje podczas konsyliów odbywających się cztery razy w roku. Na tych posiedzeniach, a także w bieżących pracach związanych z wykonywaniem przez Polskę swoich zobowiązań wynikających z wyroków Trybunału minister spraw zagranicznych RP jest reprezentowany przez pełnomocnika ministra spraw zagranicznych do spraw postępowań przed Europejskim Trybunałem Praw Człowieka lub jego zastępcę ${ }^{34}$. Komitet Ministrów jest istotnym organem, którego zadaniem jest zabezpieczenie tego, by państwa nie pomijały — swoimi działaniami lub zaniechaniami — skutków wyroków.

Zgodnie $\mathrm{z}$ art. 46 Konwencji rolą ustawodawcy jest uchwalanie ustaw stanowiących wykonanie wyroków ETPC; w ich przypadku inicjatywa i dalsza działalność parlamentu staje się kluczowa ${ }^{35}$. Przyjmuje on akty normatywne mające na celu usunięcie lub korektę normy prawnej, która była przyczyną stwierdzonego przez Trybunał naruszenia praw człowieka. Ma także za zadanie weryfikować, czy projekty nowych aktów prawnych, przedłożonych przez podmioty dysponujące inicjatywą legislacyjną, są zgodne z Konwencją ${ }^{36}$.

${ }^{31}$ W. Sanetra, Skuteczność Konwencji czy skuteczność wyroków Europejskiego Trybunału Praw Człowieka?, [w:] Zapewnienie efektywności orzeczeń sądów międzynarodowych w polskim porządku prawnym, red. A. Wróbel, Warszawa 2011, s. 78.

${ }^{32}$ I.C. Kamiński, R. Kownacki, K. Wierczyńska, Wykonywanie orzeczeń Europejskiego Trybunału Praw Człowieka w polskim systemie prawnym, [w:] Zapewnienie efektywności orzeczeń..., s. 98.

${ }^{33}$ Zgodnie z art. 14 Statutu Rady Europy każde państwo członkowskie posiada w Komitecie Ministrów jednego przedstawiciela, którym jest minister spraw zagranicznych lub jego delegat. W praktyce organ ten zbiera się bardzo rzadko w składzie ministrów. Najczęściej obraduje w składzie stałych przedstawicieli państw akredytowanych przy Radzie Europy. Działa wówczas w formule Komitetu Delegatów Ministrów.

${ }^{34}$ Pełnomocnik został powołany zarządzeniem nr 7 Ministra Spraw Zagranicznych z dnia 27 października 2003 r. w sprawie ustanowienia i zadań Pełnomocnika Ministra Spraw Zagranicznych do spraw postępowań przed Europejskim Trybunałem Praw Człowieka (Dz. Urz. MSZ z 2003 r. nr 4, poz. 53, ze zm.). R. Kropiwnicki, Wykonywanie wyroków Europejskiego Trybunału Praw Człowieka w Polsce, [w:] Dwadzieścia lat obowiazywania Konstytucji RP. Polska myśl konstytucyjna a międzynarodowe standardy demokratyczne, red. J. Jaskiernia, K. Spryszak, Toruń 2017, s. 497-498.

${ }^{35}$ A. Donald, P. Leach, Parliaments and the European Court of Human Rights, Oxford 2016, s. 65-111.

${ }^{36}$ A. Bodnar, Instytucjonalne aspekty wykonywania wyroków Europejskiego Trybunału Praw Człowieka $w$ sferze stanowienia prawa, [w:] Zapewnienie efektywności orzeczeń sadów międzynarodowych w polskim porzadku prawnym, red. A. Wróbel, Warszawa 2011, s. 270; E. Gierach, Analiza prawna dotyczaca obowiązków parlamentu narodowego w zwiazku z wdrażaniem wyroków Europejskiego Trybunału Praw Człowieka, [w:] Wykonywanie wyroków Europejskiego Trybunału Praw Człowieka przez Sejm, Warszawa 2012, s. 40. 
Państwom stronom Konwencji pozostawiona jest pewna swoboda w zakresie wyboru środków, które mają zostać podjęte w procesie wdrażania zmian w systemie prawa. Państwo przedstawia konkretne rozwiązania czy to w zakresie poprawy jakości praktyki administracyjnej, czy też zmian o charakterze legislacyjnym, a po stronie Komitetu Ministrów pozostaje ich ocena. Dokonywana jest bowiem analiza stopnia kompletności i adekwatności proponowanych przez państwo działań — w zależności od tego, co było źródłem naruszenia Konwencji stwierdzonego przez Trybuna ${ }^{37}$. Najistotniejsze jednak jest, aby podejmowane działania w przedmiocie wykonania wyroku ETPC dawały gwarancję skutecznego, a nie iluzorycznego wykonania orzeczenia Trybunału ${ }^{38}$.

Zgodnie z wymogami Rady Europy polski rząd ustanowił swojego przedstawiciela przed ETPC, tj. pełnomocnika rządu do spraw postępowań przed ETPC (tzw. agenta rządu). Polska aktywnie przyczynia się do tworzenia nowych standardów „naprawy” obszarów prawa krajowego uznanych przez ETPC za wymagające ingerencji ustawodawcy. Jak wskazano w opisującym wymagane działania krajowe raporcie Helsińskiej Fundacji Praw Człowieka: „Plan działania [action plan] stanowi wykaz prac, jakie należy podjąć w celu wykonania środków generalnych, należą do nich m.in. zmiany legislacyjne czy też zmiany w praktyce poszczególnych organów władzy. Raporty z działań [action reports] przedkładane są, gdy władze uznają, że plan działań został zrealizowany, a wyrok należy uznać za wykonany. Na podstawie raportu rządu Komitet Ministrów decyduje o zamknięciu sprawy lub zobowiązuje państwo do wykonania dodatkowych działań. W ramach prac nad wykonaniem poszczególnych założeń pełnomocnik współpracuje $\mathrm{z}$ odpowiednimi resortami. $\mathrm{Z}$ działań podejmowanych przez pełnomocnika od 2012 r. opracowywane są roczne raporty, podsumowujące działania związane z wykonaniem [wyroków]"39.

Program działań rządu w sprawie wykonywania wyroków Europejskiego Trybunału Praw Człowieka wobec Rzeczypospolitej Polskiej został przyjęty przez Radę Ministrów dnia 17 maja 2007 r. ${ }^{40}$ Mając na celu zapewnienie realizacji w Polsce wytycznych, które wynikają z orzeczeń wydawanych przez Trybunał, zarządzeniem nr 73 Prezesa Rady Ministrów z dnia 19 lipca 2007 r. w sprawie utworzenia Zespołu do spraw Europejskiego

${ }^{37}$ A. Szklanna, Rola parlamentu krajowego w wykonywaniu wyroków Europejskiego Trybunału Praw Człowieka, [w:] Reprezentacja Rzeczypospolitej Polskiej przed Europejskim Trybunałem Praw Człowieka - ponad dwie dekady doświadczeń Ministerstwa Spraw Zagranicznych, Warszawa 2018, s. 91-96; I. Wrońska, op. cit., s. 204.

${ }^{38} \mathrm{Na}$ temat roli Sejmu RP i parlamentów krajowych w wykonywaniu wyroków ETPC vide opinie prawne C. Mika, M. Balcerzaka, M. Ziółkowskiego oraz E. Gierach [w:] Wykonywanie wyroków Europejskiego Trybunału Praw Człowieka przez Sejm, Warszawa 2012, s. 5-44.

${ }^{39}$ D. Bychawska-Siniarska, Wstęp o instytucjonalnym systemie wykonywania wyroków w Polsce, [w:] Wyrok w Strasburgu to nie koniec! Raport na temat wykonywania wyroków Europejskiego Trybunatu Praw Człowieka, red. P. Kładoczny, K. Wiśniewska, wyd. 2, Warszawa 2019, s. 11. Vide także I.C. Kamiński, R. Kownacki, K. Wierczyńska, op. cit., s. 107.

40 J. Stańczyk, Perspektywa historyczna postępowań przeciwko Polsce przed Europejskim Trybunatem Praw Człowieka, [w:] Reprezentacja Rzeczypospolitej Polskiej przed Europejskim Trybunałem Praw Człowieka - ponad dwie dekady doświadczeń Ministerstwa Spraw Zagranicznych, Warszawa 2018, s. 22. 
Trybunału Praw Człowieka ${ }^{41}$ powołany został przez ówczesnego premiera Jarosława Kaczyńskiego pierwszy w Polsce organ mający kompleksowy mandat do zajmowania się sprawami Konwencji i Trybunału. Funkcjonuje on pod przewodnictwem MSZ. Organ ten, działający w formule zespołu międzyresortowego, organu opiniodawczo-doradczego Prezesa Rady Ministrów, działa do dziś. Stał się on w kolejnych latach istotnym instrumentem wypracowywania rozwiązań zmierzających do efektywnego wykonywania wyroków Trybunału ${ }^{42}$. Zespół stanowi także rzetelne źródło informacji, podnosząc tym samym świadomość na temat znaczenia standardów Konwencji w wielu krajowych instytucjach i organach. W ramach jego prac aktywnie współdziałają wszystkie ministerstwa i inne właściwe centralne organy administracji rządowej, a także najwyższe sądy, Kancelaria Prezydenta RP, Sejm i Senat, Najwyższa Izba Kontroli, Rzecznik Praw Obywatelskich $^{43}$, Rzecznik Praw Dziecka, samorządy prawnicze oraz najaktywniejsze organizacje pozarządowe. Zespół analizuje problemy wynikające z komunikowanych skarg i wydawanych przez Trybunał wyroków, ale również poddaje analizie możliwe scenariusze legislacyjne zmierzające do realizacji wytycznych ujętych w danym wyroku. Działalność Zespołu ds. ETPC opiera się przede wszystkim na spotkaniach cyklicznych oraz pracach zespołów roboczych (powoływanych przez agenta rządu ad hoc do prac nad wykonywaniem konkretnego orzeczenia), często z udziałem zaproszonych ekspertów, przedstawicieli parlamentu; podczas tych spotkań opracowywane są raporty dotyczące planów prac legislacyjnych ${ }^{44}$. Zespół ds. ETPC nie sprawuje funkcji kierowniczej w zakresie wykonywania wyroków ETPC. Ma on jedynie wypracowywać stanowiska oraz propozycje rozwiązań odnośnie do koncepcji służącej wykonaniu wyroków ETPC, natomiast decyzja w tym względzie należy do Rady Ministrów. Na niej także spoczywa odpowiedzialność za podjęcie określonych działań, co jest podkreślone przez obowiązek przedstawienia sprawozdania poszczególnym komisjom parlamentarnym ${ }^{45}$.

${ }^{41}$ Tekst ujednolicony zarządzenia nr 73: <https://bip.kprm.gov.pl/kpr/bip-rady-ministrow/organy-pomoc nicze/organy-pomocnicze-preze/159,Zespol-do-spraw-Europejskiego-Trybunalu-Praw-Czlowieka.html>, dostęp 18 II 2020.

${ }^{42}$ Do podstawowych zadań Zespołu ds. ETPC należy m.in. wypracowywanie stanowisk rządu w odniesieniu do komunikowanych skarg i wydawanych przez Trybunał wyroków, analizowanie zgodności z Konwencją najważniejszych projektów aktów prawnych, a także przedstawianie stosownych propozycji. Zespół ponadto monitoruje wykonywanie przez ministrów wyroków i decyzji Trybunału oraz może formułować propozycje odpowiednich działań. Ministrowie właściwi w zależności od przedmiotu naruszenia Konwencji stwierdzonego przez Trybunał mają obowiązek przetłumaczenia i rozpowszechnienia wyroku Trybunału, a także przygotowania planu działań i raportu z jego wykonania w terminach określonych w zarządzeniu. Zespót do spraw ETPC, MSZ, <https://www.gov.pl/web/dyplomacja/zespol-do-spraw-etpc>, dostęp 18 II 2020; R. Kropiwnicki, Wykonywanie..., s. 499-503.

${ }^{43}$ T. Bichta, Rzecznik Praw Obywatelskich, [w:] Ustrój organów ochrony prawnej, red. B. Szmulik, M. Żmigrodzki, Lublin 2001, s. 239.

${ }^{44}$ Wykonywanie orzeczeń Europejskiego Trybunału Praw Człowieka, MSZ, <https://www.msz.gov.pl/ pl/polityka_zagraniczna/europejski_trybunal_praw_czlowieka/wykonywanie_orzeczen_europejskiego_ trybunalu_praw_czlowieka/>, dostęp 18 II 2020.

${ }^{45}$ Współpraca agenta rządu z parlamentem w zakresie wykonywania wyroków ETPC obejmuje m.in. uczestnictwo w posiedzeniach komisji parlamentarnych, na których omawiane są raporty roczne przedstawiane przez pełnomocnika MSZ. Ponadto możliwy jest udział przedstawicieli Kancelarii Sejmu oraz Kancelarii Senatu, jak również indywidualnych posłów i senatorów w posiedzeniach Zespołu ds. ETPC. 
Orzecznictwo ETPC uprawnia do sformułowania tezy, że prawo do dobrej (prawidłowej i poprawnej) legislacji może być upatrywane jako swoiste „prawo człowieka”. Realizacja dobrej legislacji w kontekście praw człowieka to takie działanie podmiotów uczestniczących w procesie stanowienia prawa, które uwzględniając normy prawa krajowego oraz międzynarodowego, w sposób szczególny kształtują sytuację indywidualnej jednostki, jak i ogółu podmiotów. W sensie pozytywnym prawo do dobrej legislacji związane jest z obowiązkiem działania organów prawodawczych polegającym na zachowaniu odpowiedniej jakości i rzetelności wydawanych aktów prawnych, a w sensie negatywnym oznacza zakaz tworzenia prawa złego, czyli niespełniającego stawianych mu wymogów materialnych i formalnych. W orzecznictwie polskich sądów i Trybunału Konstytucyjnego [dalej: TK] podkreśla się związek prawidłowej legislacji z zapewnieniem skutecznej ochrony wolności i praw człowieka ${ }^{46}$. Wśród reguł legislacyjnych cechujących prawidłową legislację wywiedzionych z klauzuli demokratycznego państwa prawnego (zawartej w art. 2 Konstytucji RP) wymienić można m.in. poszanowanie standardów międzynarodowych, zakaz retroakcji prawa, obowiązek zachowania potrzebnej vacatio legis czy też obowiązek poszanowania praw słusznie nabytych ${ }^{47}$.

ETPC nie poprzestaje tylko na formalnym przypisaniu państwu odpowiedzialności międzynarodowej czy zasądzeniu odszkodowania w konkretnej sprawie dla skarżącego. Art. 1 Konwencji zobowiązuje bowiem każde państwo do zapewnienia każdemu człowiekowi podlegającemu jego jurysdykcji praw i wolności w niej określonych ${ }^{48}$. Konwencja nie precyzuje, co należy rozumieć przez termin ,zapewnienie”, jednakże z bogatego orzecznictwa ETPC wynika, że obowiązek zapewnienia jest zarówno obowiązkiem negatywnym, a więc jest to obowiązek powstrzymania się od naruszania praw człowieka, jak i obowiązkiem pozytywnym - obowiązkiem działania na rzecz praw człowieka ${ }^{49}$. W konsekwencji dla pełnego wykonania wyroku stwierdzającego naruszenie EKPC niezbędne jest podjęcie wszystkich środków prawnych

Osoby te nie są stałymi członkami Zespołu, ale mogą służyć głosem doradczym, uczestniczą w spotkaniach na zaproszenie przewodniczącego Zespołu, wyjaśniając wówczas m.in. intencję i formułę zmian legislacyjnych wprowadzonych w formie poprawek poselskich lub senackich. Posłowie i senatorowie biorą ponadto udział w organizowanych przez pełnomocnika MSZ konferencjach naukowych poświęconych zagadnieniom wynikającym z wyroków ETPC. Praktykuje się także organizowanie na forum Komisji Praw Człowieka, Praworządności i Petycji Senatu RP spotkań z udziałem gości zagranicznych będących autorytetami w dziedzinie praw człowieka. Vide Seminaria Warszawskie, MSZ, <https://msz.gov.pl/pl/p/msz_pl/ polityka_zagraniczna/europejski_trybunal_praw_czlowieka/warsaw_seminars/>, dostęp 18 II 2020; W Senacie o zwiększeniu roli parlamentów narodowych $w$ wykonywaniu wyroków ETPC, Kancelaria Senatu RP, $<$ https://www.senat.gov.pl/aktualnosci/art,7929,w-senacie-o-zwiekszeniu-roli-parlamentow-narodowychw-wykonywaniu-wyrokow-etpc.html>, dostęp 18 II 2020.

${ }^{46}$ Konstytucja III RP w tezach orzeczniczych Trybunału Konstytucyjnego i wybranych sądów, red. M. Zubik, Warszawa 2011, s. 19-23.

47 J. Zaleśny, Zasady prawidłowej legislacji, „Studia Politologiczne” 2009, nr 13, s. 11-46.

48 M. Balcerzak, Podstawy międzynarodowej ochrony praw człowieka. Zarys wykładu z materiałami źródłowymi, Toruń 2017, s. 136.

49 Wyrok z 9 lutego 1967 r. w tzw. belgijskiej sprawie językowej (skarga nr 1474/62 i inne), wyrok z 13 czerwca 1979 r. w sprawie Marckx vs. Belgia (skarga nr 6833/74) czy wyrok z 9 października 1979 r. w sprawie Airey vs. Irlandia (skarga nr 6289/73). 
koniecznych do wykonania Konwencji ${ }^{50}$. Ten obowiązek w szczególności może polegać na podjęciu środków legislacyjnych, gdy źródłem naruszenia praw człowieka była ustawa lub doprowadzenie do zmiany praktyki organów wymiaru sprawiedliwości ${ }^{51}$.

Należy zgodzić się ze stanowiskiem Cezarego Mika, który uważa, że „troska o pełne wykonywanie zobowiązań międzynarodowych państw członkowskich Rady Europy w dziedzinie praw człowieka, zwłaszcza tych, które wynikają z Konwencji i wyroków Europejskiego Trybunału Praw Człowieka, jest wyrażana w pracach Zgromadzenia Parlamentarnego [Rady Europy]"52 , będącego emanacją parlamentów krajowych. Zgromadzenie nie ma jednak uprawnień władczych. Może zatem formułować jedynie postulaty czy kierować zalecenia ${ }^{53}$. Znajduje to odzwierciedlenie także w poglądzie prezentowanym przez Michała Balcerzaka, który stwierdza, że „zobowiązanie do wykonania wyroku Trybunału jest de facto zobowiązaniem rezultatu i z punktu widzenia zobowiązań konwencyjnych nie ma znaczenia, które organy państwa-strony mają wiodącą rolę w doprowadzeniu do wykonania wyroku ETPC. Bezdyskusyjne jest natomiast to, że główny ciężar odpowiedzialności za wykonanie wyroków ETPC spoczywa na władzy wykonawczej, która powinna ustanowić efektywne mechanizmy współpracy z organami władzy ustawodawczej i sądowniczej, w szczególności, gdy wykonanie orzeczenia ETPC zależy od podjęcia konkretnych działań przez legislatywę lub judykatywę"54.

\section{Szczególna rola parlamentu}

Ewelina Gierach słusznie podkreśla, iż: „Obok przepisów samej Konwencji obowiązki parlamentów krajowych w zakresie wdrażania wyroków ETPC wynikają z zaleceń Komitetu Ministrów oraz rezolucji Zgromadzenia Parlamentarnego Rady Europy [ZPRE]"55.

${ }^{50}$ J. Jaskiernia, Mechanizmy zwiększenia skuteczności wykonywania wyroków Europejskiego Trybunału Praw Człowieka, [w:] Uniwersalny i regionalny wymiar ochrony praw czlowieka. Nowe wyzwania - nowe rozwiazania, t. 1, red. J. Jaskiernia, Warszawa 2014; A. Wiśniewski, Koncepcja marginesu oceny w orzecznictwie ETPCz, Gdańsk 2008, s. 23-81.

${ }^{51}$ L. Garlicki, Rola sędziego krajowego w procesie wykonywania orzeczeń Europejskiego Trybunatu Praw Człowieka, [w:] IX Seminarium Warszawskie. Dysfunkcje polskiego prawa - jak poprawić system środków prawnych w Polsce?, Warszawa 2016, s. 10, <https://www.msz.gov.pl/resource/8639074df905-41ed-981a-e9df92e27226:JCR>, dostęp 18 II 2020. Przykładem realizacji obowiązku dostosowania treści prawa krajowego do treści prawa międzynarodowego jest implementacja przepisów międzynarodowego prawa karnego, które - jak ujmował to Manfred Lachs — są jednym ze środków zabezpieczenia wykonywania przepisów z zakresu praw człowieka. E. Karska, Manfred Lachs wobec ludobójstwa i zbrodni wojennych, [w:] Manfred Lachs - wybitny prawnik świata, red. Z. Galicki, T. Kamiński, K. Myszona-Kostrzewa, Warszawa 2011, s. 383-385. Vide także E. Socha, Zakres wtaczenia katalogu zbrodni objętych jurysdykcja Międzynarodowego Trybunału Karnego do polskiego prawa karnego materialnego, „Przegląd Sejmowy" 2007, nr 5(82), s. 253-266.

${ }_{52}$ C. Mik, Opinia w sprawie roli parlamentu (Sejmu) w wykonywaniu wyroków Europejskiego Trybunału Praw Człowieka, [w:] Wykonywanie wyroków Europejskiego Trybunału Praw Człowieka przez Sejm, Warszawa 2012, s. 10.

${ }^{53}$ Ibidem.

${ }_{54}$ M. Balcerzak, Analiza prawna..., s. 20.

${ }_{55}$ E. Gierach, op. cit., s. 39. 
W tym kontekście należy mieć oczywiście na uwadze, że uchwały tych organów są aktami prawa „miękkiego” (soft law), co bynajmniej nie obniża ich merytorycznego znaczenia oraz tego, że są one pewnymi — choć, jak sama nazwa wskazuje, ,miękkimi" - wzorcami postępowania ${ }^{56}$.

W zaleceniu Rec (2004)5 Komitetu Ministrów Rady Europy dla państw członkowskich w sprawie kontroli zgodności projektów aktów prawnych oraz istniejącego prawa i praktyki administracyjnej ze standardami wyrażonymi w Europejskiej Konwencji Praw Człowieka czytamy przykładowo, że parlamenty narodowe mają obowiązek zapewnienia istnienia właściwych i skutecznych mechanizmów umożliwiających, jeśli zaistnieje taka potrzeba, kontrolę zgodności z Konwencją obowiązujących aktów prawnych, łącznie z przepisami zawartymi w rozporządzeniach, zarządzeniach i okólnikach, a także jak najszybszego dostosowania przepisów i praktyki administracyjnej, aby zapobiec naruszeniom Konwencji ${ }^{57}$. Uprzednia weryfikacja projektowanego prawa pod kątem zgodności z Konwencją powoduje, że państwo redukuje ryzyko naruszenia Konwencji, co pozwoli w przyszłości na zmniejszenie liczby aplikacji (skarg na naruszenia) przesyłanych do $\mathrm{ETPC}^{58}$.

Dobrą praktyką w tym zakresie jest systematyczny nadzór nad projektami ustaw przeprowadzany zarówno na szczeblu wykonawczym, jak i parlamentarnym, a także gdy dokumenty te konsultowane są przez niezależne organy ${ }^{59}$. Oznacza to konieczność funkcjonowania mechanizmów uprzedniej weryfikacji przyjmowanego ustawodawstwa. Parlamenty mogą ponadto rozliczać władzę wykonawczą z realizacji zobowiązań za pomocą różnych instrumentów, np. przez stanowiska komisji sejmowych, działania podejmowane przez komisje śledcze, interpelacje i zapytania czy dyskusję na temat sprawozdań przedstawianych parlamentowi przez odpowiednie władze i instytucje ${ }^{60}$.

${ }^{56} \mathrm{Na}$ temat istoty soft law vide A. Wiśniewski, Soft law, [w:] Wielka encyklopedia prawa..., t. 4, s. $453-454$.

${ }^{57}$ Zalecenie Rec (2004)5 Komitetu Ministrów Rady Europy dla państw członkowskich w sprawie kontroli zgodności projektów aktów prawnych oraz istniejącego prawa i praktyki administracyjnej ze standardami wyrażonymi w Europejskiej Konwencji Praw Człowieka, przyjęte przez Komitet Ministrów w dniu 12 maja 2004 r., na 114 Sesji Komitetu Ministrów (12-13 maja 2004), <https://www.msz.gov.pl/resource/ 2459451a-fa37-4feb-aed5-b98445515424:JCR>, dostęp 18 II 2020.

${ }^{58}$ W dniach 19-20 kwietnia 2012 r. miała miejsce Konferencja Wysokiego Szczebla na temat Przyszłości Europejskiego Trybunału Praw Człowieka, która opracowała tzw. deklarację z Brighton. Raport został sfinalizowany w lutym 2016 r. W opracowaniu tego dokumentu uczestniczyły nie tylko państwa członkowskie RE, ale także eksperci zewnętrzni (m.in. dwaj byli sędziowie Trybunału). Głównym przesłaniem deklaracji z Brighton było uświadomienie państwom stronom, że powinny wdrażać praktyczne środki zapewniające uwzględnienie postanowień Konwencji w procesie tworzenia prawa, w tym poprzez korzystanie przez parlamenty krajowe informacji w przedmiocie zgodności z Konwencją projektów prawa proponowanych przez rząd. Podkreślano, że Konwencję należy brać pod uwagę w procesie legislacyjnym w niektórych aktach wymieniając ją bezpośrednio jako dyrektywę interpretacyjną. Tekst deklaracji z Brighton w thumaczeniu roboczym jest dostępny pod adresem $<$ https://msz.gov.pl/resource/30bf3fd4-87ab-41e $8 \mathrm{~b}$ 3d8-28eda3b3cfc4:JCR>, dostęp 18 II 2020.

${ }_{59}$ M. Żak, Soft law jako instrument koordynacji regulacyjnej good governance, „Przegląd Legislacyjny" 2019, nr 1(107), s. 9-32.

${ }^{60}$ A. Bodnar, Wykonywanie orzeczeń..., s. 324. 
Partycypacja niezależnych organizacji zajmujących się prawami człowieka na różnych etapach procesu legislacyjnego pozwoliłaby na uniknięcie wprowadzania rozwiązań generujących ryzyko wszczęcia postępowania przed Trybunałem ${ }^{61}$. W doktrynie formułuje się pogląd, że w niektórych sytuacjach, gdy projekt miałby dotyczyć praw fundamentalnych, takie konsultacje powinny być obligatoryjne ${ }^{62}$. Jeśli rząd po konsultacjach decyduje się nie brać pod uwagę zgłoszonych uwag, oznacza to, że akceptuje odpowiedzialność za polityczne i prawne konsekwencje takiej decyzji ${ }^{63}$.

Aktualnie na tle innych państw członkowskich Rady Europy skala spraw polskich kształtuje się zasadniczo na podobnym poziomie od kilku lat ${ }^{64}$. Wiele zagadnień prawnych, które były przedmiotem rozstrzygnięć ETPC, wpłynęło w sposób znaczący na refleksję legislacyjną i podjęcie odpowiednich działań prawodawczych w kierunku zbliżenia ustawodawstwa polskiego do standardu konwencyjnego ${ }^{65}$. Na uwagę w tym zakresie zasługują m.in. sprawy: Broniowski vs. Polska ${ }^{66}$, Hutten-Czapska vs. Polska ${ }^{67}$, Kudła vs. Polska ${ }^{68}$,

${ }^{61}$ Raporty NGOs dotyczące legislacji krajowej: Podsumowania, Obserwatorium Demokracji, <http:// obserwatoriumdemokracji.p1/podsumowania/>, dostęp 18 II 2020; Publikacje, Helsińska Fundacja Praw Człowieka, <https://www.hfhr.pl/publikacje/publikacje-programow/>, dostęp 18 II 2020.

${ }^{62}$ E. Popławska, Konsultacje społeczne jako instrument kontroli legalności ustawy w Sejmie, [w:] Kontrola legalności ustawy w Sejmie, red. P. Radziewicz, Warszawa 2015, s. 207-239.

${ }^{63}$ P. Bednarz, Najlepsze praktyki w zakresie konsultacji społecznych w Holandii, [w:] Dobre rzadzenie poprzez wkład społeczny. Zwiększenie udzialu organizacji pozarzadowych w procesie legislacyjnym, red. M. Bąk, P. Kulawczuk, A. Szcześniak, Warszawa 2011, s. 91; D. Sobczyński, Organizacje pozarzadowe i obywatele w rzadowym procesie tworzenia prawa w wybranych krajach europejskich, Warszawa 2015, s. 12.

${ }^{64}$ Zgodnie z danymi ETPC za 2019 r. Polska znalazła się na 10. miejscu pod względem liczby zawisłych aktualnie skarg: 1250, co stanowi 2,1\% ogółu skarg. W 2019 r. zakomunikowano rządowi polskiemu konieczność zajęcia stanowiska w kwestii 253 skarg, co oznacza wzrost w porównaniu z $2018 \mathrm{r}$. o 115 skarg. Spadła znacząco liczba złożonych przez RP deklaracji jednostronnych przyznających, że doszło do naruszenia praw i wolności - w 2019 r. było ich 31, podczas gdy w 2017 r. - 347, a w 2018 r. - 279. Spadła również znacząco w porównaniu $\mathrm{z}$ latami poprzednimi liczba zawartych ugód - w $2019 \mathrm{r}$. było ich 16, zaś w 2017 r. 170, a w 2018 r. 123. W 2019 r. wydano przeciwko Polsce 12 wyroków, aż w 11 stwierdzono naruszenie Europejskiej Konwencji Praw Człowieka. European Court of Human Rights, Analysis and Statistics 2019, January 2020, <https://www.echr.coe.int/Documents/Stats_analysis_2019 ENG.pdf>, dostęp 18 II 2020; European Court of Human Rights, Violations by Article and by State, $<$ https://www.echr.coe.int/Documents/Stats_violation_1959_2019_ENG.pdf>, dostęp 18 II 2020.

${ }^{65}$ Jeszcze w 2011 r. liczba orzeczeń znajdujących się w fazie wykonywania pod nadzorem Komitetu Ministrów wynosiła ponad 900. Za sukces należy uznać to, że Polska jest jednym z liderów pod względem zamkniętych postępowań strasburskich (zgodnie z ogłoszonym 4 kwietnia 2018 r. raportem Komitetu Ministrów Rady Europy na temat wykonywania wyroków w 2017 r.). Polska w systemie Europejskiej Konwencji Praw Człowieka, Warszawa 2018, <https://www.gov.pl/web/dyplomacja/polska-w-systemieeuropejskiej-konwencji-praw-czlowieka>, dostęp 18 II 2020.

${ }_{66}$ Wyrok z 22 czerwca 2004 r. w sprawie Broniowski vs. Polska, skarga nr 31443/96; confer J. Prokop-Gralińska, Kwestie problematyczne w realizacji roszczeń zabużańskich - próba analizy praktyki, „Studia Prawno-Ekonomiczne" 2013, t. 88, s. 141-156; eadem, Realizacja roszczeń zabużańskich z tytułu pozostawienia nieruchomości poza obecnymi granicami Rzeczypospolitej Polskiej, Łódź 2016.

${ }^{67}$ Wyrok z 19 czerwca 2006 r. w sprawie Hutten-Czapska vs. Polska, skarga nr 35014/97.

${ }^{68}$ Wyrok z 26 października 2000 r. w sprawie Kudła vs. Polska, skarga nr 30210/96; confer Polska przed Europejskim Trybunałem Praw Człowieka. Sprawy wiodace: sprawa Kudła przeciwko Polsce z 2000 r., red. E.H. Morawska, Warszawa 2019. 
Rutkowski vs. Polska ${ }^{69}$, Potomska i Potomski vs. Polska ${ }^{70}$, Tysiąc vs. Polska ${ }^{71}$, Kędzior vs. Polska ${ }^{72}$.

Zgromadzenie Parlamentarne Rady Europy wielokrotnie wskazywało na kluczową rolę parlamentów krajowych w skutecznej implementacji wyroków ETPC. W rezolucji 1516 (2006) o wykonywaniu wyroków ETPC z 2 października 2006 r. wezwano parlamenty narodowe do wdrażania specjalnych procedur oraz mechanizmów, które zapewniałyby efektywną kontrolę działań podejmowanych w ramach prac legislacyjnych. Zaznaczono, że formy tego nadzoru mogą obejmować m.in. debatę na temat głównych tez wyroku, odpowiedzialność polityczną rządu, a także pytania lub interpelacje. Podkreślono również, że szczególnie parlament powinien odgrywać znaczącą rolę w koordynacji i nadzorze prowadzonej współpracy pomiędzy organami władzy państwowej. Powinien prowadzić monitoring orzecznictwa ETPC i rozpowszechniać je przy jednoczesnym dokonywaniu analizy zgodności z przepisami EKPC obowiązujących aktów prawnych. Dodatkowo warto, aby dokonywał weryfikacji zgodności projektów aktów normatywnych z przepisami EKPC na kolejnych etapach postępowania ustawodawczego. Zadania te Sejm i Senat mogą realizować w ramach funkcji ustawodawczej, przyjmując nowe lub nowelizując już obowiązujące ustawy ${ }^{73}$.

${ }^{69}$ Wyrok z 7 lipca 2015 r. w sprawie Rutkowski i inni vs. Polska, skargi nr 72287/10, 13927/11 i $46187 / 11$.

${ }^{70}$ Wyrok z 29 marca 2011 r. w sprawie Potomska i Potomski vs. Polska, skarga nr 33949/05.

${ }^{71}$ Wyrok z 20 marca 2007 r. w sprawie Tysiąc vs. Polska, skarga nr 5410/03.

${ }_{72}$ Wyrok z 12 października 2012 r. w sprawie Kędzior vs. Polska, skarga nr 45026/07.

${ }^{73}$ W trakcie kadencji parlamentarnej 2015-2019 (VIII kadencji Sejmu i IX kadencji Senatu) z jednym wyjątkiem - projekty ustaw implementujących wyroki ETPC były przedłożeniami rządowymi. To odstępstwo to inicjatywa ustawodawcza Senatu. Projekt ustawy o zmianie ustawy o systemie ubezpieczeń społecznych oraz niektórych innych ustaw (druk nr 72 z 14 stycznia 2016 r.) przygotowała senacka Komisja Ustawodawcza. Czytamy w nim m.in., że: „Istotne w [...] kontekście (wyroku TK z dnia 28 lutego 2012 r. (sygn. akt K 5/11)) jest również stanowisko Sądu Najwyższego wyrażone w związku z wyrokiem Europejskiego Trybunału Praw Człowieka w sprawie Moskal przeciwko Polsce (rozstrzygnięcie z dnia 15 września 2009 r., skarga nr 10373/05). Otóż w orzeczeniu z dnia 21 września 2010 r. (sygn. akt III UK 94/09) Sąd Najwyższy dokonał reinterpretacji art. 114 ust. 1 [ustawy z dnia 17 grudnia 1998 r. o emeryturach i rentach z Funduszu Ubezpieczeń Społecznych (Dz.U. z 2009 r. nr 153, poz. 1227, ze zm.) — przyp. K.G.-B. i K.K.)] i sformułował kryteria ograniczające wzruszalność prawomocnych decyzji rentowych. [...] Podzielając przytoczony wywód Sądu Najwyższego co do przesłanek ograniczających wzruszalność decyzji wydanych przez organy rentowe, Trybunał wyraził jednak przekonanie, iż tego rodzaju zastrzeżenia powinny znaleźć bezpośredni wyraz w ustawie, jako że w tym wypadku mamy do czynienia z prawem poręczonym na poziomie ustawy zasadniczej (art. 67 ust. 1). Konieczne jest zatem zachowanie $\mathrm{w}$ analizowanym zakresie wymogów określonych w art. 31 ust. 3 Konstytucji”. Ibidem, s. 4-5. W trakcie prac senackich projekt ten był następnie rozpatrywany wspólnie przez Komisję Rodziny, Polityki Senioralnej i Społecznej, Komisję Praw Człowieka, Praworządności i Petycji oraz Komisję Ustawodawczą. Prace senackie zakończyły się przyjęciem uchwały Senatu Rzeczypospolitej Polskiej z dnia 7 lipca 2016 r. w sprawie wniesienia do Sejmu projektu ustawy o zmianie ustawy o emeryturach i rentach z Funduszu Ubezpieczeń Społecznych oraz niektórych innych ustaw (druk sejmowy $\mathrm{nr} 778$ z dnia 7 lipca 2016 r.). W wyniku tego działania przyjęta została ustawa z dnia 10 lutego 2017 r. o zmianie ustawy o emeryturach i rentach z Funduszu Ubezpieczeń Społecznych oraz niektórych innych ustaw (Dz.U. poz. 715). Warto jednak odnotować, że w toku prac senackich i sejmowych projekt 
Sejm może w tym zakresie egzekwować także swoje uprawnienia posiadane w ramach wykonywania funkcji kontrolnej wobec rządu ${ }^{74}$.

Warto przy tym podkreślić, że istotnym etapem prac parlamentarnych, podczas którego odbywają się debaty często na wysokim poziomie szczegółowości oraz merytoryki, są posiedzenia poszczególnych komisji. Nie należy bowiem zapominać, że projekt na tym etapie również może ulegać modyfikacjom $\mathrm{w}$ ramach zgłaszanych poprawek czy to poselskich, czy senackich. Instytucja „poprawki” stwarza bowiem możliwość działania ad hoc, jeśli dostrzeże się problem mogący w przyszłości doprowadzić do stwierdzenia naruszenia Konstytucji RP czy Konwencji ${ }^{75}$.

Zgodnie z postulatami ZPRE zawartymi w rezolucji z 26 stycznia $2011 \mathrm{r}$. nr 1787 $(2011)^{76}$ państwa strony Konwencji powinny potraktować jako istotne wzmocnienie aktywności władzy ustawodawczej w kontekście współpracy z władzą wykonawczą, tak aby optymalnie i skutecznie realizować plan wykonywania wyroków ETPC. Jak słusznie wskazuje M. Balcerzak, zgodnie z treścią art. 9 Konstytucji RP Sejm jest współodpowiedzialny za przestrzeganie przez Polskę zobowiązań międzynarodowych, w tym i tych wynikających z wyroków ETPC. Ustanowienie „specjalnego” mechanizmu nadzoru parlamentarnego w odniesieniu do tego obszaru nie leży jednak w sferze zobowiązań międzynarodowych RP. Autor ten uznaje przy tym, że „potrzeba udziału parlamentu w wykonywaniu wyroków ETPC nie jest «wymuszona» przez treść zobowiązań międzynarodowych (a tym bardziej rezolucji ZPRE), lecz wynika z przesłanek prakseologicznych oraz dążenia do możliwie efektywnej współpracy organów państwa w realizacji konstytucyjnej zasady poszanowania prawa międzynarodowego" 77.

Kolejna ważna rezolucja ZPRE pochodzi z 23 czerwca 2011 r. (rezolucja nr 1823 (2011)) i przyjęta została pod wiele mówiącym tytułem „Parlamenty krajowe: gwaranci praw człowieka w Europie" 78 . W odniesieniu do wyroków Europejskiego Trybunału Praw Człowieka stwierdzono, że parlamenty narodowe są wyjątkowo dobrze usytuowane w ścieżce legislacyjnej, z jednej strony po to, aby kontrolować rządy co do szybkiego i efektywnego wykonywania wyroków ETPC, a z drugiej strony, aby wspierać dynamikę prac na dalszych etapach ${ }^{79}$.

ten był przedstawiany jako działanie zmierzające do wykonania wyroku TK. Senat zainteresował się tym problemem nie ze względu na wyrok ETPC, a dopiero ze względu na będący poniekąd jego refleksem wyrok TK. Senat realizował bowiem to zadanie w ramach przyjętej już wcześniej na siebie roli inicjatora zmian ustawowych, których konieczność wprowadzenia wynikała z wyroków TK.

74 E. Gierach, op. cit., s. 41.

${ }^{75}$ K. Kubuj, M. Laskowska, Instytucja poprawki legislacyjnej a kontrola legalności ustawy, [w:] Kontrola legalności ustawy w Sejmie, red. P. Radziewicz, Warszawa 2015, s. 127-162.

${ }^{76}$ Rezolucja Zgromadzenia Parlamentarnego Rady Europy z 26 stycznia 2011 r. nr 1787 (2011), $<$ http://assembly.coe.int/Main.asp?link=/Documents/AdoptedText/tall/ERES1787.htm>, dostęp 18 II 2020.

77 M. Balcerzak, Analiza prawna..., s. 21.

78 Debata Zgromadzenia Parlamentarnego w dniu 23 czerwca 2011 r. (25 sesja) (vide Doc. 12636, raport Komisji Spraw Prawnych i Praw Człowieka, sprawozdawca: Christos Pourgourides). Tekst przyjęty przez Zgromadzenie w dniu 23 czerwca 2011 r. (25 sesja). Resolution 1823 (2011) Final version. National parliaments: guarantors of human rights in Europe, Parliamentary Assembly, $<$ http://assembly.coe.int/nw/ xml/XRef/Xref-XML2HTML-en.asp?fileid=18011\&lang=en>, dostęp 18 II 2020.

${ }^{79}$ C. Mik, op. cit., s. 11. 
W związku z tym Zgromadzenie Parlamentarne Rady Europy sformułowało wobec parlamentów narodowych pewne oczekiwania ${ }^{80}$. Skupiono się na działalności parlamentu narodowego w kontekście inicjowania zmian lub ich dokonywania w trakcie procedur legislacyjnych oraz działalności władz centralnych i lokalnych, a także sądów i admini$\operatorname{stracji}^{81}$. Za istotny uznano również obowiązek informowania parlamentów krajowych nie tylko o orzeczeniach zapadłych w sprawach przeciwko danemu państwu, ale również o orzeczeniach, które ETPC wydał w sprawach dotyczących innych państw, jeżeli mogą mieć one wpływ na ustawodawstwo danego państwa. Chodzi zatem o możliwość stosowania zasady res interpretata orzeczeń Trybunału ${ }^{82}$.

Projekty ustaw, które są kierowane na ręce Marszałka Sejmu, mogą na wielu różnych etapach podlegać kontroli pod kątem zgodności z ratyfikowanymi umowami międzynarodowymi, w tym umowami dotyczącymi praw człowieka. Należy jednak zwrócić uwagę, że szczególną rolę w procesie opiniowania odgrywa Konstytucja RP, ponieważ to jej standard jest kluczowy do wyznaczania norm poszanowania praw i wolności ${ }^{83}$. Zasadniczo można wyróżnić pewne etapy, kiedy taka weryfikacja może mieć miejsce: etap wstępnej kontroli projektów ustaw przez Marszałka Sejmu oraz etap prac ustawodawczych, w tym rozpatrywanie projektów przez właściwe komisje sejmowe $^{84}$, a także trzy czytania projektów ustaw ${ }^{85}$. Należy pamiętać, że obie izby parlamentu są reprezentantami obywateli wybranymi w wyborach powszechnych, zatem odpowiedzialność posłów i senatorów wobec obywateli jest znacząco inna niż relacja rząd-obywatel. Na Sejmie i Senacie spoczywa ogromna odpowiedzialność za

${ }^{80}$ P. Grzegorczyk, Skutki wyroków ETPCz w krajowym porządku prawnym, „Przegląd Sądowy” 2006, nr 6, s. 22; C. Mik, op. cit., s. 12.

${ }^{81}$ C. Mik, op. cit., s. 12.

82 A. Szklanna, op. cit., s. 94.

${ }^{83}$ Konstytucja w zakresie przestrzegania praw jednostek wyznacza zasadniczo takie same, a niekiedy nawet wyższe standardy niż Konwencja. Confer A. Bodnar, Instytucjonalne..., s. 277.

${ }^{84}$ Omawiając rolę polskiego parlamentu, należy przypomnieć powołanie w Sejmie Podkomisji stałej do spraw wykonywania przez Polskę wyroków Europejskiego Trybunału Praw Człowieka. Miało to miejsce 5 lutego 2014 r. na posiedzeniu wspólnym Komisji Sprawiedliwości i Praw Człowieka oraz Komisji Spraw Zagranicznych Sejmu RP. Mandat podkomisji obejmował szczegółowe rozpatrywanie informacji Rady Ministrów na temat stanu wykonywania przez Polskę wyroków ETPC, monitorowanie wyroków Trybunału, które zostały wydane w sprawach przeciwko Polsce, i przygotowanie projektów dezyderatów lub opinii Komisji Sprawiedliwości i Praw Człowieka oraz Komisji Spraw Zagranicznych w sprawie realizacji przez Radę Ministrów obowiązku wykonania przez Polskę wyroków ETPC. Był to element generalnego trendu promowanego przez Zgromadzenie Parlamentarne Rady Europy, mającego na celu zwiększenie zaangażowania parlamentów krajowych oraz zacieśnianie współpracy pomiędzy poszczególnymi podmiotami odpowiedzialnymi za wdrażanie wyroków. Polska była jednym z pierwszych państw członkowskich Rady Europy, które powołało tego typu podkomisję. Podkomisja odbyła 6 posiedzeń i przestała funkcjonować pod koniec 2015 r., tj. wraz z zakończeniem VII kadencji Sejmu. Pomimo apeli HFPC i RPO nie została powołana na nowo, co zostało odnotowane przez sprawozdawców ZPRE. Podkomisja stała do spraw wykonywania przez Polske wyroków Europejskiego Trybunału Praw Człowieka (SZA01S), Sejm RP, <http://www.sejm.gov.pl/Sejm7.nsf/ PosKomZrealizowane.xsp?komisja=SZA01S>, dostęp 18 II 2020. Na temat genezy i działalności Podkomisji vide szerzej R. Kropiwnicki, System..., s. 307-308.

${ }^{85}$ A. Bodnar, Wykonywanie orzeczeń..., s. 395. 
jakość stanowionego prawa, na etapie parlamentarnym rola Rady Ministrów formalnie staje się mniej wiodąca, lecz nie wykluczona.

Idealną, choć na razie niestety logistycznie nieosiągalną sytuacją byłoby obligatoryjne sprawdzanie zgodności każdego projektu ustawy z prawem międzynarodowym, w tym z Konwencją. Należy się przy tym zgodzić się z Robertem Kropiwnickim, który wskazywał, że na obecnym etapie możliwości legislacyjnych niezasadne jest jednak dokonywanie przez Sejm i Senat ,przeglądu wszystkich projektów ustaw pod kątem zgodności z Konwencją. Z punktu widzenia praktyki parlamentarnej należy uznać, że byłoby to niepotrzebne skomplikowanie procedury legislacyjnej. Głównie z tego względu, że zdecydowana większość aktów wydawanych przez Sejm i Senat nie ma nic wspólnego z prawami człowieka i postanowieniami Konwencji. Bardziej zasadne wydaje się podjęcie «miękkich» kroków na rzecz zwiększenia wiedzy o ważnych wyrokach Trybunału zarówno w sprawach przeciwko Polsce, jak i innym krajom, wśród posłów i senatorów oraz pracowników Biura Legislacyjnego i Biura Analiz Sejmowych"\$6. Takie praktyczne podejście nie stoi oczywiście na przeszkodzie, by w sytuacji dostrzeżenia w danym projekcie ustawy potencjalnych regulacji z zakresu praw człowieka poddać go analizie zgodności z Konwencją na podstawie już istniejącego instrumentarium, które jest sformułowane w regulaminach obu izb.

Co do zasady można stwierdzić, że mimo braku formalnego wymogu uzyskania opinii o zgodności projektu ustawy z ratyfikowanymi umowami międzynarodowymi, w tym z umowami dotyczącymi praw człowieka, regulamin Sejmu ${ }^{87}$ stwarza możliwości odpowiedniej weryfikacji projektów ustaw poprzez: zapraszanie ekspertów na posiedzenia Komisji; wyspecjalizowany charakter Komisji Sprawiedliwości i Praw Człowieka oraz Komisji Ustawodawczej; zorganizowanie wysłuchania publicznego; skorzystanie z pomocy Biura Analiz Sejmowych; zabieranie głosu na forum Sejmu przez przedstawicieli organów konstytucyjnych oraz innych organów władzy publicznej ${ }^{88}$. Regulamin Sejmu ${ }^{89}$ nie wyklucza również możliwości podejmowania działań zmierzających do realizacji zobowiązań wynikających z Konwencji. Zgodnie z samą nazwą, a w konsekwencji i zakresem właściwości Komisji Sprawiedliwości i Praw Człowieka, jednym z głównych celów jej działania są „,sprawy przestrzegania praw człowieka” (pkt 23 załącznika do regulaminu Sejmu $)^{90}$. Tego rodzaju regulacja pozwala, aby organy Sejmu oraz poszczególni

${ }^{86}$ R. Kropiwnicki, System..., s. 308.

${ }^{87}$ Uchwała Sejmu Rzeczypospolitej Polskiej z dnia 30 lipca 1992 r. — Regulamin Sejmu Rzeczypospolitej Polskiej, M.P. z 1992 r. nr 26, poz. 185, ze zm.; W. Odrowąż-Sypniewski, Komentarz do art. 124, [w:] Komentarz do Regulaminu Sejmu Rzeczypospolitej Polskiej, red. A. Szmyt, Warszawa 2018, s. 541-569.

${ }^{8}$ A. Bodnar, Wykonywanie orzeczeń..., s. 398-399.

${ }^{89}$ Obwieszczenie Marszałka Sejmu Rzeczypospolitej Polskiej z dnia 3 października 2019 r. w sprawie ogłoszenia jednolitego tekstu uchwały Sejmu Rzeczypospolitej Polskiej — Regulamin Sejmu Rzeczypospolitej Polskiej, M.P. z 2019 r. poz. 1028.

90 Pkt 23 załącznika do regulaminu Sejmu RP (,Przedmiotowy zakres działania komisji sejmowych”): „Do zakresu działania Komisji Sprawiedliwości i Praw Człowieka należą sprawy przestrzegania prawa i praworządności, sądów, prokuratury, notariatu, adwokatury i obsługi prawnej, funkcjonowania samorządów adwokackiego i radcowskiego, sprawy przestrzegania praw człowieka". P. Radziewicz, Rekomendacje..., s. 2. 
posłowie mogli wystąić do Rady Ministrów o przedstawienie dokumentacji w zakresie realizacji praw człowieka w Polsce. Ponadto zgodnie z art. 153 regulaminu Sejmu wskazane w nim organy Sejmu mogą wzywać do składania wyjaśnień oraz osobistego stawiennictwa ministrów lub innych przedstawicieli rządu, a także na podstawie art. 69 regulaminu Sejmu - uchwalać rezolucje, deklaracje, apele, oświadczenia. Co więcej, zgodnie z art. 191 regulaminu Sejmu posłowie licznie składają interpelacje i zapytania poselskie, które często dotyczą działań podejmowanych przez rząd w celu wykonania konkretnego wyroku ETPC ${ }^{91}$. Także Senat RP posiada komisję, w zakresie kompetencji której znajdują się prawa człowieka. Jest to Komisja Praw Człowieka, Praworządności i Petycji. Jej kompetencje są jednak węższe niż komisji sejmowej, gdyż zgodnie z art. 95 ust. 2 Konstytucji RP Senat RP — w przeciwieństwie do Sejmu RP — nie wykonuje funkcji kontrolnej wobec Rady Ministrów. Należy jednak zwrócić uwagę na fakt, że poprzez pozyskiwanie corocznych sprawozdań od Rzecznika Praw Obywatelskich ${ }^{92}$, Rzecznika Praw Dziecka ${ }^{93}$ oraz Trybunału Konstytucyjnego ${ }^{94}$ Sejm oraz Senat otrzymują bieżącą informację m.in. o stanie przestrzegania praw i wolności w Rzeczypospolitej Polskiej95.

Rząd RP przedstawił dotychczas osiem raportów z wykonywania wyroków ETPC, za lata 2012-2019, przy czym pierwszy został sporządzony w wyniku dezyderatu Komisji Sprawiedliwości i Praw Człowieka Sejmu $\mathrm{RP}^{96}$. Chociaż pierwszy raport rządu RP

${ }_{91}$ Przykładem takiego wystąpienia jest m.in. interpelacja nr $1961 \mathrm{w}$ sprawie wykonania wyroku Europejskiego Trybunału Praw Człowieka z dnia 26 maja 2011 r. w sprawie R.R. przeciwko Polsce, złożona przez posłankę Wandę Nowicką do Prezesa Rady Ministrów 15 lutego 2012 r., <http://www.sejm.gov.pl/ sejm7.nsf/interpelacja.xsp?typ=INT\&nr=1961\&view=null>, dostęp 18 II 2020.

${ }^{92}$ Informacja stanowi wykonanie art. 212 Konstytucji RP, który przewiduje, że Rzecznik corocznie informuje Sejm i Senat o swojej działalności oraz o stanie przestrzegania wolności i praw człowieka i obywatela, jak również art. 19 ust. 2 ustawy z dnia 15 lipca 1987 r. o Rzeczniku Praw Obywatelskich (Dz.U. z 2001 r. $\mathrm{nr}$ 14, poz. 147, ze zm.), ustanawiającego obowiązek podania informacji Rzecznika do wiadomości publicznej, oraz art. 124 regulaminu Sejmu i art. 24 regulaminu Senatu. Informacje roczne, Biuletyn Informacji Publicznej Rzecznika Praw Obywatelskich, <https://bip.brpo.gov.pl/pl/category/informacje-roczne-o-dzia lalnosci-rpo>, dostęp 18 II 2020; Informacje roczne o działalności RPO, Rzecznik Praw Obywatelskich, $<$ https://www.rpo.gov.pl/pl/content/informacje-roczne-o-dzialalnosci-rpo>, dostęp 18 II 2020.

${ }_{93}$ Zgodnie z art. 12 ust. 1 ustawy z dnia 6 stycznia 2000 r. o Rzeczniku Praw Dziecka (Dz.U. z 2015 r. poz. 2086) Rzecznik przedstawia Sejmowi i Senatowi corocznie, nie później niż do dnia 31 marca, informację o swojej działalności i uwagi o stanie przestrzegania praw dziecka. Sprawozdania z działalności, Rzecznik Praw Dziecka, <https://brpd.gov.pl/sprawozdania-z-dzialalnosci/>, dostęp 18 II 2020.

${ }^{94}$ Zgodnie z art. 13 ust. 1 ustawy z dnia 30 listopada 2016 r. o organizacji i trybie postępowania przed Trybunałem Konstytucyjnym (Dz. U. z 2019 r. poz. 2393) Prezes Trybunału przedkłada corocznie Sejmowi oraz Senatowi informację o istotnych problemach wynikających z działalności i orzecznictwa Trybunału. Informacja o istotnych problemach wynikających z działalności i orzecznictwa Trybunału Konstytucyjnego w $2018 \mathrm{roku}$, Sejm RP, <http://www.sejm.gov.pl/Sejm9.nsf/PrzebiegProc.xsp?nr=98\& SessionID=6F4D1379FB6D45AA1ED1BF3F3CE39B2F58712E21>, dostęp 18 II 2020.

${ }_{95}$ P. Radziewicz, Rekomendacje..., s. 2-3.

${ }^{96}$ Dezyderat nr 1 Komisji Sprawiedliwości i Praw Człowieka uchwalony na posiedzeniu w dniu 12 kwietnia 2012 r. do Prezesa Rady Ministrów w sprawie wykonywania wyroków Europejskiego Trybunału Praw Człowieka, <http://orka.sejm.gov.pl/opinie7.nsf/nazwa/spc_d1/\$file/spc_d1.pdf>, dostęp 18 II 2020. Petny zapis przebiegu posiedzenia Komisji Sprawiedliwości i Praw Człowieka (Nr 17) z dnia 12 kwietnia 2012 r., Kancelaria Sejmu RP, <http://orka.sejm.gov.pl/zapisy7.nsf/0/5C739BCEF7DAD200C12579 E6004535AB/\%24File/0043007.pdf>, dostęp 18 II 2020. 
wzbudził pewne kontrowersje, to analiza kolejnych wskazywać może na wypracowanie przez Radę Ministrów przejrzystej formuły informowania parlamentu o stanie wykonywania wyroków ${ }^{97}$.

Rada Ministrów, na wniosek Ministra Spraw Zagranicznych, przyjęła dnia 11 maja 2020 r. raport z wykonywania wyroków Europejskiego Trybunału Praw Człowieka przez Polskę za 2019 r. ${ }^{98}$, który został przekazany m.in. przewodniczącym Komisji Sprawiedliwości i Praw Człowieka Sejmu RP oraz Komisji Praw Człowieka, Praworządności i Petycji Senatu RP, gdzie odbyła się dyskusja nad przedłożonym materiałem ${ }^{99}$.

Na koniec 2019 r. liczba wydanych przeciwko Polsce orzeczeń znajdujących się w nadzorze Komitetu Ministrów Rady Europy spadła do 98 (w tym 69 wyroków i 29 decyzji zatwierdzających ugodę). Jest to najniższa liczba orzeczeń w procesie wykonywania, jaką odnotowała Polska od czasu utworzenia Zespołu ds. Europejskiego Trybunału Praw Człowieka i rozpoczęcia systemowych działań nakierowanych na wzmocnienie implementacji wyroków Trybunału i upowszechniania standardów wynikających z Konwencji ${ }^{100}$. Polskie orzeczenia stanowiły na koniec 2019 r. około 1,8\% wszystkich orzeczeń znajdujących się w procesie wykonywania pod nadzorem Komitetu Ministrów $\mathrm{RE}^{101}$.

\section{Podsumowanie}

Parlament nie jest organem reprezentującym państwo na płaszczyźnie prawnomiędzynarodowej. Dlatego też obowiązek realizacji zobowiązań międzynarodowych, w tym wykonania wyroków ETPC, spoczywa na władzy wykonawczej. Organem władzy wykonawczej mającej szczególnie silne umocowanie w Konstytucji RP oraz — co nie mniej ważne - odpowiednie instrumentarium jest rząd. Nie oznacza to oczywiście, że inne organy państwa, działając w ramach swoich konstytucyjnych kom-

${ }^{97}$ A. Bodnar, Wykonywanie orzeczeń..., s. 295.

${ }^{98}$ Raport z wykonywania wyroków Europejskiego Trybunału Praw Człowieka przez Polskę za 2019 r., Warszawa 2020, <https://www.gov.pl/web/dyplomacja/raporty-roczne-rzadu-na-temat-wykonywania-orzeczenetpc>, dostęp 24 VI 2020.

${ }^{99}$ Podczas dyskusji na temat raportu za 2018 r., która odbyła się na forum Komisji Praw Człowieka, Praworządności i Petycji Senatu RP, podkreślano, że wykonywanie wyroków ETPC wymaga ścisłej współpracy władzy ustawodawczej, wykonawczej i sądowniczej. Raport z wykonywania wyroków..., s. $18-19$.

${ }^{100}$ Liczba orzeczeń ETPC w sprawach przeciwko Polsce w nadzorze Komitetu Ministrów Rady Europy (dane na koniec każdego roku): $2010-731 ; 2011-924 ; 2012-872 ; 2013-705 ; 2014-498$; $2015-313 ; 2016-223 ; 2017-124 ; 2018-100$. Dane pozyskane na podstawie raportów rocznych przekazywanych przez Pełnomocnika Ministra Spraw Zagranicznych do spraw Postępowań przed Europejskim Trybunałem Praw Człowieka, $<$ https://www.gov.pl/web/dyplomacja/raporty-roczne-rzadu-na-tematwykonywania-orzeczen-etpc>, dostęp 24 VI 2020.

${ }^{101}$ Raport z wykonywania wyroków..., s. 39-40. 
petencji, nie uczestniczą na szczeblu krajowym w wykonywaniu wyroków ETPC. Niekiedy może być to niezbędne, gdy istnieje potrzeba zmiany treści ustawy lub przyjęcia nowej ustawy (władza ustawodawcza) lub gdy w indywidualnej sprawie należy podjąć, w tym podjąć na nowo (wznowić), postępowanie przed sądem (władza sądownicza). Ma to miejsce, gdy odpowiednio to ustawa lub jej brak albo wyrok sądu krajowego lub jego brak były źródłem naruszenia Konwencji wskazanego przez ETPC.

ZPRE podkreśla, że parlamenty narodowe posiadają szczególne obowiązki w zakresie implementacji wyroków ETPC. Po części są to reguły wywiedzione z Konwencji (hard law), a po części są to nowe rozwiązania z zakresu prawa „miękkiego” (soft law). Niezależnie od źródeł regulacji parlamenty krajowe mają w tym zakresie do odegrania istotną rolę.

Pewne standardy działania parlamentów krajowych wynikają także z orzecznictwa samego ETPC. Dotyczy to m.in. prawa do dobrej (prawidłowej i poprawnej) legislacji. Jak już wskazano, w sensie pozytywnym prawo do dobrej legislacji związane jest z obowiązkiem działania organów prawodawczych, w tym Sejmu i Senatu, polegającym na zachowaniu odpowiedniej jakości i rzetelności wydawanych aktów prawnych, a w sensie negatywnym oznacza zakaz tworzenia przez nie prawa złego, czyli niespełniającego stawianych mu wymogów materialnych i formalnych.

Sejm i Senat tworzą prawo, którego zgodność z Konwencją może być przedmiotem wyroku ETPC. Wtedy też - z inicjatywy własnej lub innych podmiotów wyposażonych w inicjatywę ustawodawczą - dostosowują jego treść do wymogów EKPC. Wyspecjalizowane struktury, które na bieżąco w Polsce zajmują się monitorowaniem wykonywania wyroków ETPC, funkcjonują w obrębie władzy wykonawczej. To ona ma szczególny obowiązek podejmowania działań w tym zakresie, tym bardziej że to ona jest na płaszczyźnie prawnomiędzynarodowej — choć w imieniu całego państwa — rozliczana z wykonywania zobowiązań zewnętrznych. Dlatego też inicjatywa ustawodawcza w tym zakresie co do zasady wykonywana jest przez rząd. Nie pozbawia to jednak analogicznych uprawnień obu izb polskiego parlamentu.

W ramach funkcji kontrolnej Sejmu, która jest realizowana wobec Rady Ministrów, izba ta ma możliwość podejmowania wielu działań mogących przyczynić się do poprawy realizacji praw człowieka (dezyderaty, interpelacje, wysłuchania publiczne, komisje śledcze wota nieufności itd.). Funkcji kontrolnej nie pełni natomiast Senat. Może jednak mocą swojego autorytetu pochylać się nad tą problematyką, tym bardziej że obie izby są adresatami informacji obejmujących także te zagadnienia, składanych przez określone prawem władze i instytucje.

Reasumując, można stwierdzić, że choć to rząd jest podmiotem zobowiązanym do wykonywania zobowiązań państwa na płaszczyźnie prawnomiędzynarodowej, to do ich realizacji w krajowym porządku prawnym niekiedy niezbędne jest działanie parlamentu. Obie izby (Sejm i Senat) mogą też podejmować działania zachęcające rząd do zwiększonej aktywności w tym zakresie. 


\section{Bibliografia}

\section{ŹRÓDŁA}

A kty prawne

Konstytucja Rzeczypospolitej Polskiej z dnia 2 kwietnia 1997 r., Dz.U. nr 97, poz. 483, ze zm.

Konwencja o ochronie praw człowieka i podstawowych wolności, sporządzona w Rzymie dnia 4 listopada 1950 r., ETS No. 005, ze zm., Dz.U. z 1993 r. nr 61, poz. 284, ze zm.

Obwieszczenie Marszałka Sejmu Rzeczypospolitej Polskiej z dnia 3 października 2019 r. w sprawie ogłoszenia jednolitego tekstu uchwały Sejmu Rzeczypospolitej Polskiej - Regulamin Sejmu Rzeczypospolitej Polskiej, M.P. z 2019 r. poz. 1028.

Statut Rady Europy, przyjęty w Londynie dnia 5 maja 1949 r., ETS No. 001, Dz.U. z 1994 r. nr 118, poz. 565 i 566.

Uchwała nr 190 Rady Ministrów z dnia 29 października 2013 r. Regulamin pracy Rady Ministrów, M.P. z 2016 r. poz. 1006 i 1204, z 2018 r. poz. 114 i 278 oraz z 2019 r. poz. 137.

Uchwała Sejmu Rzeczypospolitej Polskiej z dnia 30 lipca 1992 r. — Regulamin Sejmu Rzeczypospolitej Polskiej, M.P. z 1992 r. nr 26, poz. 185.

Ustawa z dnia 15 lipca 1987 r. o Rzeczniku Praw Obywatelskich, Dz.U. z 2001 r. nr 14, poz. 147, ze zm.

Ustawa z dnia 8 sierpnia 1996 r. o Radzie Ministrów, Dz.U. z 2019 r. poz. 1171.

Ustawa z dnia 6 stycznia 2000 r. o Rzeczniku Praw Dziecka, Dz.U. z 2015 r. poz. 2086.

Ustawa z dnia 30 listopada 2016 r. o organizacji i trybie postępowania przed Trybunałem Konstytucyjnym, Dz.U. z 2019 r. poz. 2393.

Ustawa z dnia 10 lutego 2017 r. o zmianie ustawy o emeryturach i rentach z Funduszu Ubezpieczeń Społecznych oraz niektórych innych ustaw, Dz.U. poz. 715.

\section{Orzecznictwo}

Wyrok ETPC z 9 lutego 1967 r. w tzw. belgijskiej sprawie językowej, skarga nr 1474/62 i inne. Wyrok ETPC z 13 czerwca 1979 r. w sprawie Marckx vs. Belgia, skarga nr 6833/74.

Wyrok ETPC z 9 października 1979 r. w sprawie Airey vs. Irlandia, skarga nr 6289/73.

Wyrok ETPC z 26 października 2000 r. w sprawie Kudła vs. Polska, skarga nr 30210/96.

Wyrok ETPC z 22 czerwca 2004 r. w sprawie Broniowski vs. Polska, skarga nr 31443/96.

Wyrok ETPC z 19 czerwca 2006 r. w sprawie Hutten-Czapska vs. Polska, skarga nr 35014/97.

Wyrok ETPC z 20 marca 2007 r. w sprawie Tysiąc vs. Polska, skarga nr 5410/03.

Wyrok ETPC z 15 września 2009 r. w sprawie Moskal i inni vs. Polska, skarga nr 10373/05.

Wyrok ETPC z 29 marca 2011 r. w sprawie Potomska i Potomski vs. Polska, skarga nr 33949/05.

Wyrok ETPC z 12 października 2012 r. w sprawie Kędzior vs. Polska, skarga nr 45026/07.

Wyrok ETPC z 7 lipca 2015 r. w sprawie Rutkowski i inni vs. Polska, skargi nr 72287/10, 13927/11 i 46187/11.

Wyrok SN z 21 września 2010 r., sygn. akt III UK 94/09.

Wyrok TK z 28 lutego 2012 r., sygn. akt K 5/11.

\section{Źródła in ternetowe}

Dezyderat nr 1 Komisji Sprawiedliwości i Praw Człowieka uchwalony na posiedzeniu w dniu 12 kwietnia 2012 r. do Prezesa Rady Ministrów w sprawie wykonywania wyroków Europejskiego Trybunału Praw Człowieka, <http://orka.sejm.gov.pl/opinie7.nsf/nazwa/spc d1/\$file/spc_d1.pdf $>$.

European Court of Human Rights, Analysis and Statistics 2019, January 2020, <https://www. echr.coe.int/Documents/Stats_analysis_2019_ENG.pdf>. 
European Court of Human Rights, Violations by Article and by State, <https:/www.echr.coe.int/ Documents/Stats_violation_1959_2019_ENG.pdf>.

Informacja o istotnych problemāch wynikających z działalności i orzecznictwa Trybunału Konstytucyjnego w 2018 roku, Sejm RP, <http://www.sejm.gov.pl/Sejm9.nsf/PrzebiegProc.xsp? $\mathrm{nr}=98 \&$ SessionID $=6$ F4D1379FB6D45AA1ED1BF3F3CE39B2F58712E21>.

Informacje roczne, Biuletyn Informacji Publicznej Rzecznika Praw Obywatelskich, $<$ https://bip. brpo.gov.pl/pl/category/informacje-roczne-o-dzialalnosci-rpo $>$.

Informacje roczne o działalności RPO, Rzecznik Praw Obywatelskich, <https://www.rpo.gov. $\mathrm{pl} / \mathrm{pl} /$ content/informacje-roczne-o-dzialalnosci-rpo $>$.

Interpelacja nr $1961 \mathrm{w}$ sprawie wykonania wyroku Europejskiego Trybunału Praw Człowieka z dnia 26 maja 2011 r. w sprawie R.R. przeciwko Polsce, <http://www.sejm.gov.pl/sejm7. nsf/interpelacja.xsp?typ=INT\&nr=1961\&view=null $>$.

Komisje senackie, Senat RP, <https://www.senat.gov.pl/prace/komisje-senackie/>.

Petne zapisy posiedzeń komisji sejmowych, Sejm RP, <https://www.sejm.gov.pl/Sejm8.nsf/ biuletyny.xsp>.

Petny zapis przebiegu posiedzenia Komisji Sprawiedliwości i Praw Człowieka (Nr 17) z dnia 12 kwietnia 2012 r., Kancelaria Sejmu RP, <http://orka.sejm.gov.pl/zapisy7.nsf/0/5C739 BCEF7DAD200C12579E6004535AB/\%24File/0043007.pdf>.

Podkomisja stała do spraw wykonywania przez Polske wyroków Europejskiego Trybunatu Praw Człowieka (SZA01S), Sejm RP, <http://www.sejm.gov.pl/Sejm7.nsf/PosKomZrealizowane. xsp?komisja=SZA01S $>$.

Podsumowania, Obserwatorium Demokracji, <http://obserwatoriumdemokracji.pl/podsumo wania/>.

Polska w systemie Europejskiej Konwencji Praw Człowieka, Departament ds. Postępowań przed Międzynarodowymi Organami Ochrony Praw Człowieka Ministerstwa Spraw Zagranicznych, Warszawa 2018, <https://www.gov.pl/web/dyplomacja/polska-w-systemie-europejskiejkonwencji-praw-czlowieka>.

Przewodnik senatora. Kontakty międzyparlamentarne, Kancelaria Senatu, Warszawa 2019, $<$ https://senat.gov.pl/sklad/przewodnik-senatora/>.

Publikacje, Helsińska Fundacja Praw Człowieka, <https://www.hfhr.pl/publikacje/publikacjeprogramow/>.

Rada Legislacyjna, <https://radalegislacyjna.gov.pl/>.

Raport z wykonywania wyroków Europejskiego Trybunału Praw Człowieka przez Polskę za 2019 r., Ministerstwo Spraw Zagranicznych, Warszawa 2020, <https://www.gov.pl/web/ dyplomacja/raporty-roczne-rzadu-na-temat-wykonywania-orzeczen-etpc $>$.

Resolution 1823 (2011) Final version. National parliaments: guarantors of human rights in Europe, Parliamentary Assembly, <http://assembly.coe.int/nw/xml/XRef/Xref-XML2HTMLen.asp?fileid $=18011 \&$ lang $=$ en $>$.

Rezolucja Zgromadzenia Parlamentarnego Rady Europy z 26 stycznia 2011 r. nr 1787 (2011), $<$ http://assembly.coe.int/Main.asp?link=/Documents/AdoptedText/tall/ERES1787.htm>.

Rządowe Centrum Legislacji, <https://www.rcl.gov.pl/>.

Rzecznik Praw Obywatelskich, <https://www.rpo.gov.pl/pl/content/interwencje-w-sprawie-zmia ny-przepisow>.

Seminaria Warszawskie, MSZ, <https://msz.gov.pl/pl/p/msz_pl/polityka_zagraniczna/europejski_ trybunal_praw_czlowieka/warsaw_seminars/>.

Sprawozdania z działalności, Rzecznik Praw Dziecka, <https://brpd.gov.pl/sprawozdaniaz-dzialalnosci/>.

$W$ Senacie o zwiększeniu roli parlamentów narodowych $w$ wykonywaniu wyroków ETPC, Kancelaria Senatu RP, <https://www.senat.gov.pl/aktualnosci/art,7929,w-senacie-o-zwiekszeniuroli-parlamentow-narodowych-w-wykonywaniu-wyrokow-etpc.html>. 
Wykonywanie orzeczeń Europejskiego Trybunału Praw Człowieka, MSZ, <https://www.msz.gov. $\mathrm{pl} / \mathrm{pl} /$ polityka_zagraniczna/europejski_trybunal_praw_czlowieka/wykonywanie_orzeczen_ europejskiego trybunalu_praw_czlowieka/>.

Zalecenie Rec (2004)5 Komitetu Ministrów Rady Europy dla państw członkowskich w sprawie kontroli zgodności projektów aktów prawnych oraz istniejącego prawa i praktyki administracyjnej ze standardami wyrażonymi w Europejskiej Konwencji Praw Człowieka, przyjęte przez Komitet Ministrów w dniu 12 maja 2004 r., na 114 Sesji Komitetu Ministrów (12-13 maja 2004), <https://www.msz.gov.pl/resource/2459451a-fa37-4feb-aed5b98445515424:JCR>.

Zarządzenie nr 7 Ministra Spraw Zagranicznych z dnia 27 października 2003 r. w sprawie ustanowienia i zadań Pełnomocnika Ministra Spraw Zagranicznych do spraw postępowań przed Europejskim Trybunałem Praw Człowieka, Dz. Urz. MSZ z 2003 r. nr 4, poz. 53, ze zm.

Zarządzenie nr 73 Prezesa Rady Ministrów z dnia 19 lipca 2007 r. w sprawie utworzenia Zespołu do spraw Europejskiego Trybunału Praw Człowieka, tekst jedn. <https://bip. $\mathrm{kprm}$.gov.pl/kpr/bip-rady-ministrow/organy-pomocnicze/organy-pomocnicze-preze/159, Zespol-do-spraw-Europejskiego-Trybunalu-Praw-Czlowieka.html>.

Zespót do spraw ETPC, MSZ, <https://www.gov.pl/web/dyplomacja/zespol-do-spraw-etpc>.

\section{PIŚMIENNICTWO}

Balcerzak M., Analiza prawna na temat wykonywania wyroków Europejskiego Trybunatu Praw Człowieka przez Sejm, [w:] Wykonywanie wyroków Europejskiego Trybunału Praw Człowieka przez Sejm, Biuro Analiz Sejmowych, Warszawa 2012.

Balcerzak M., Odpowiedzialność państwa strony Europejskiej konwencji o ochronie praw człowieka i podstawowych wolności. Studium prawnomiędzynarodowe, Towarzystwo Naukowe Organizacji i Kierownictwa „Dom Organizatora”, Toruń 2013.

Balcerzak M., Podstawy międzynarodowej ochrony praw człowieka. Zarys wykładu z materiałami źródłowymi, Towarzystwo Naukowe Organizacji i Kierownictwa „Dom Organizatora”, Torun 2017.

Barcik J., Srogosz T., Prawo międzynarodowe publiczne, wyd. 3, C.H.Beck, Warszawa 2017.

Barkhuysen T., Emmerik M. Van, A Comparative View on the Execution of the Judgments of the European Court of Human Rights, [w:] European Court of Human Rights: Remedies and Execution of Judgments, red. T.A. Christou, J.P. Raymond, British Institute of International and Comparative Law, London 2005.

Bednarz P., Najlepsze praktyki w zakresie konsultacji społecznych w Holandii, [w:] Dobre rzadzenie poprzez wkład społeczny. Zwiększenie udziału organizacji pozarzadowych w procesie legislacyjnym, red. M. Bąk, P. Kulawczuk, A. Szcześniak, Fundacja Instytut Badań nad Demokracją i Przedsiębiorstwem Prywatnym, Warszawa 2011.

Bichta T., Rzecznik Praw Obywatelskich, [w:] Ustrój organów ochrony prawnej, red. B. Szmulik, M. Żmidrodzki, Wydawnictwo Uniwersytetu Marii Curie-Skłodowskiej, Lublin 2001.

Bierzanek R., Symonides J., Prawo międzynarodowe publiczne, wyd. 8, LexisNexis, Warszawa 2004.

Bodnar A., Instytucjonalne aspekty wykonywania wyroków Europejskiego Trybunału Praw Człowieka $w$ sferze stanowienia prawa, [w:] Zapewnienie efektywności orzeczeń sąów międzynarodowych w polskim porzadku prawnym, red. A. Wróbel, Wolters Kluwer Polska, Warszawa 2011.

Bodnar A., Wykonywanie orzeczeń Europejskiego Trybunału Praw Człowieka w Polsce. Wymiar instytucjonalny, Wolters Kluwer Polska, Warszawa 2018. 
Bodnar A., Pudzianowska D., Uwzględnianie Europejskiej Konwencji Praw Człowieka w procesie legislacyjnym, [w:] Rola orzecznictwa $w$ systemie prawnym, WPiA UW, Warszawa 2015.

Brzozowski W., Krzywoń A., Wiącek M., Prawa człowieka, Wolters Kluwer Polska, Warszawa 2018.

Bychawska-Siniarska D., Wstęp o instytucjonalnym systemie wykonywania wyroków w Polsce, [w:] Wyrok w Strasburgu to nie koniec! Raport na temat wykonywania wyroków Europejskiego Trybunału Praw Człowieka, red. P. Kładoczny, K. Wiśniewska, wyd. 2, Helsińska Fundacja Praw Człowieka, Warszawa 2019.

Ciżyńska A., Karakulski J., Kos K., Pyłko J., Prawo konstytucyjne wraz z orzecznictwem Trybunału Konstytucyjnego, C.H.Beck, Warszawa 2017.

Czapliński W., Wyrozumska A., Prawo międzynarodowe publiczne. Zagadnienia systemowe, wyd. 3, C.H.Beck, Warszawa 2004.

Donald A., Leach P., Parliaments and the European Court of Human Rights, Oxford University Press, Oxford 2016.

Gałka K., Zasada przestrzegania prawa międzynarodowego jako zasada konstytucyjna (art. 9 Konstytucji RP), [w:] Polskie prawo stosunków międzynarodowych. Zagadnienia wybrane, red. C. Mik, Ł. Kułaga, Towarzystwo Naukowe Organizacji i Kierownictwa „Dom Organizatora", Torun 2018.

Garlicki L., Polskie prawo konstytucyjne. Zarys wykładu, Liber, Warszawa 2001.

Garlicki L., Rola sędziego krajowego w procesie wykonywania orzeczeń Europejskiego Trybunału Praw Człowieka, [w:] IX Seminarium Warszawskie. Dysfunkcje polskiego prawa jak poprawić system środków prawnych w Polsce?, Ministerstwo Spraw Zagranicznych, Warszawa 2016.

Gierach E., Analiza prawna dotyczaca obowiązków parlamentu narodowego w zwiazku z wdrażaniem wyroków Europejskiego Trybunału Praw Człowieka, [w:] Wykonywanie wyroków Europejskiego Trybunału Praw Człowieka przez Sejm, Biuro Analiz Sejmowych, Warszawa 2012.

Góralczyk W., Sawicki S., Prawo międzynarodowe publiczne w zarysie, wyd. 16, Wolters Kluwer, Warszawa 2015.

Górecki D., Polskie prawo konstytucyjne, Wolters Kluwer Polska, Warszawa 2012.

Grzegorczyk P., Skutki wyroków ETPCz w krajowym porządku prawnym, „Przegląd Sądowy” 2006, nr 6.

Iłowiecki R., Status legislatora w organach władzy publicznej. Zawód legislator, „Przegląd Sejmowy" 2010, nr 6(101).

Jasiak A., Constitutional Constraints on Ad Hoc Legislation. A Comparative Study of the United States. Germany and the Netherlands, Intersentia, Cambridge-Antwerp-Maastricht 2011.

Jaskiernia J., Mechanizmy zwiększenia skuteczności wykonywania wyroków Europejskiego Trybunału Praw Człowieka, [w:] Uniwersalny i regionalny wymiar ochrony praw człowieka. Nowe wyzwania - nowe rozwiazania, t. 1, red. J. Jaskiernia, Wydawnictwo Sejmowe, Warszawa 2014.

Jasudowicz T., Bartosiewicz J., Fordoński R., Orzecznictwo Europejskiego Trybunału Praw Człowieka w sprawach polskich, Wydział Prawa i Administracji Uniwersytetu Warmińsko-Mazurskiego, Olsztyn 2012.

Kamiński I.C., Kownacki R., Wierczyńska K., Wykonywanie orzeczeń Europejskiego Trybunału Praw Człowieka w polskim systemie prawnym, [w:] Zapewnienie efektywności orzeczeń sąów międzynarodowych w polskim porząku prawnym, red. A. Wróbel, Wolters Kluwer Polska, Warszawa 2011.

Karska E., Manfred Lachs wobec ludobójstwa i zbrodni wojennych, [w:] Manfred Lachs - wybitny prawnik świata, red. Z. Galicki, T. Kamiński, K. Myszona-Kostrzewa, Stowarzyszenie Absolwentów Wydziału Prawa i Administracji Uniwersytetu Warszawskiego, Warszawa 2011. 
Karski K., Parlament, [w:] Wielka encyklopedia prawa, red. B. Hołyst, R. Hauser, t. 4: Międzynarodowe prawo publiczne, red. J. Symonides, D. Pyć, Fundacja „Ubi societas, ibi ius”, Warszawa 2014.

Keller H., Stone Sweet A., Assessing the Impact of the ECHR on National Legal Systems, [w:] A Europe of Rights: The Impact of the ECHR on National Legal Systems, red. H. Keller, A. Stone Sweet, Oxford University Press, Oxford 2008.

Konstytucja III RP w tezach orzeczniczych Trybunału Konstytucyjnego i wybranych sądów, red. M. Zubik, C.H.Beck, Warszawa 2011.

Kropiwnicki R., Instytucjonalizacja standardów Rady Europy na przykladzie polskiej skargi na przewlekłość postęowań sąowych i prokuratorskich, [w:] Nowe wyzwania i rozwiazania w europejskim systemie praw człowieka, red. J. Jaskiernia, K. Spryszak, Wydawnictwo Adam Marszałek, Toruń 2018.

Kropiwnicki R., System wykonywania wyroków Europejskiego Trybunału Praw Człowieka w Polsce, [w:] Aktualne wyzwania ochrony wolności i praw jednostki, red. M. Jabłoński, S. Jarosz-Żukowska, Prawnicza i Ekonomiczna Biblioteka Cyfrowa, Wydział Prawa, Administracji i Ekonomii Uniwersytetu Wrocławskiego, Wrocław 2014.

Kropiwnicki R., Wykonywanie wyroków Europejskiego Trybunału Praw Człowieka w Polsce, [w:] Dwadzieścia lat obowiazywania Konstytucji RP. Polska myśl konstytucyjna a międzynarodowe standardy demokratyczne, red. J. Jaskiernia, K. Spryszak, Wydawnictwo Adam Marszałek, Toruń 2017.

Kubuj K., Laskowska M., Instytucja poprawki legislacyjnej a kontrola legalności ustawy, [w:] Kontrola legalności ustawy w Sejmie, red. P. Radziewicz, Wydawnictwo Sejmowe, Warszawa 2015.

Kwiecień R., Transformacja umów międzynarodowych jako forma stanowienia prawa w państwie (z uwzględnieniem praktyki polskiej), „Państwo i Prawo” 1997, z. 4.

Mażewski L., Prowadzenie polityki zagranicznej w Rzeczypospolitej Polskiej, „Ruch Prawniczy, Ekonomiczny i Socjologiczny" 2009, nr 3, s. 9.

Mik C., Opinia w sprawie roli parlamentu (Sejmu) w wykonywaniu wyroków Europejskiego Trybunału Praw Człowieka, [w:] Wykonywanie wyroków Europejskiego Trybunału Praw Człowieka przez Sejm, Biuro Analiz Sejmowych, Warszawa 2012.

Nowicki M.A., Wokół Konwencji Europejskiej. Komentarz do Europejskiej Konwencji Praw Człowieka, wyd. 4, Wolters Kluwer Polska, Warszawa 2009.

Odrowąż-Sypniewski W., Komentarz do art. 124, [w:] Komentarz do Regulaminu Sejmu Rzeczypospolitej Polskiej, red. A. Szmyt, Wydawnictwo Sejmowe, Warszawa 2018.

Polska przed Europejskim Trybunałem Praw Człowieka. Sprawy wiodace: sprawa Kudła przeciwko Polsce z 2000 r., red. E.H. Morawska, C.H.Beck, Warszawa 2019.

Polskie prawo konstytucyjne, red. W. Skrzydło, wyd. 4, Oficyna Wydawnicza Verba, Lublin 2006.

Popławska E., Konsultacje społeczne jako instrument kontroli legalności ustawy w Sejmie, [w:] Kontrola legalności ustawy w Sejmie, red. P. Radziewicz, Wydawnictwo Sejmowe, Warszawa 2015.

Prokop-Gralińska J., Kwestie problematyczne w realizacji roszczeń zabużańskich — próba analizy praktyki, „Studia Prawno-Ekonomiczne” 2013, t. 88.

Prokop-Gralińska J., Realizacja roszczeń zabużańskich z tytułu pozostawienia nieruchomości poza obecnymi granicami Rzeczypospolitej Polskiej, Uniwersytet Łódzki, Łódź 2016.

Radziewicz P., Doradztwo naukowe w pracach Sejmu, ,Przegląd Sejmowy” 2013, nr 5(118).

Radziewicz P., Rekomendacje dotyczace wykonywania wyroków Europejskiego Trybunatu Praw Człowieka przez Sejm, [w:] Wykonywanie wyroków Europejskiego Trybunału Praw Człowieka przez Sejm, Biuro Analiz Sejmowych, Warszawa 2012. 
Rot H., Wartości proceduralne tworzenia prawa. Studium legislacji porównawczej, Wydawnictwo Uniwersytetu Wrocławskiego, Wrocław 1992.

Sanetra W., Skuteczność Konwencji czy skuteczność wyroków Europejskiego Trybunału Praw Człowieka?, [w:] Zapewnienie efektywności orzeczeń sąów międzynarodowych w polskim porząku prawnym, red. A. Wróbel, Wolters Kluwer Polska, Warszawa 2011.

Skuczyński P., Etyka legislatora a racjonalne tworzenie prawa, [w:] Leges ab omnibus intellegi debent. Księga XV-lecia Rządowego Centrum Legislacji, red. W. Brzozowski, A. Krzywoń, Wydawnictwo Sejmowe, Warszawa 2015.

Sobczyński D., Organizacje pozarzadowe i obywatele w rzadowym procesie tworzenia prawa w wybranych krajach europejskich, Fundacja im. Stefana Batorego, Warszawa 2015.

Socha E., Zakres właczenia katalogu zbrodni objętych jurysdykcją Międzynarodowego Trybunału Karnego do polskiego prawa karnego materialnego, „Przegląd Sejmowy” 2007, nr 5(82).

Stańczyk J., Perspektywa historyczna postępowań przeciwko Polsce przed Europejskim Trybunałem Praw Człowieka, [w:] Reprezentacja Rzeczypospolitej Polskiej przed Europejskim Trybunałem Praw Człowieka - ponad dwie dekady doświadczeń Ministerstwa Spraw Zagranicznych, Ministerstwo Spraw Zagranicznych, Warszawa 2017.

Sylwestrzak A., Władza rządzaca, władza opozycja i władza neutralna na tle tradycyjnych teorii podziału władz, [w:] Wokót wybranych problemów konstytucjonalizmu. Księga jubileuszowa Profesora Andrzeja Bałabana, red. J. Ciapała, P. Mijal, Wydawnictwo Sejmowe, Warszawa 2017.

Szklanna A., Rola parlamentu krajowego w wykonywaniu wyroków Europejskiego Trybunatu Praw Człowieka, [w:] Reprezentacja Rzeczypospolitej Polskiej przed Europejskim Trybunałem Praw Człowieka - ponad dwie dekady doświadczeń Ministerstwa Spraw Zagranicznych, Ministerstwo Spraw Zagranicznych, Warszawa 2018.

Szymanek J., Udziat czynnika eksperckiego w procesie ustawodawczym, [w:] Leges ab omnibus intellegi debent. Ksiegga XV-lecia Rzadowego Centrum Legislacji, red. W. Brzozowski, A. Krzywoń, Wydawnictwo Sejmowe, Warszawa 2015.

Wiśniewski A., Koncepcja marginesu oceny w orzecznictwie ETPCz, Fundacja Rozwoju Uniwersytetu Gdańskiego, Gdańsk 2008.

Wiśniewski A., Soft law, [w:] Wielka encyklopedia prawa, red. B. Hołyst, R. Hauser, t. 4: Międzynarodowe prawo publiczne, red. J. Symonides, D. Pyć, Fundacja „Ubi societas, ibi ius”, Warszawa 2014.

Wronkowska S., Ekspert a proces tworzenia prawa, „Państwo i Prawo” 2000, nr 9.

Wrońska I., Pozycja ustrojowa władzy wykonawczej $w$ Polsce $w$ aspekcie wykonywania wyroków Europejskiego Trybunału Praw Człowieka - wybrane zagadnienia, „Białostockie Studia Prawnicze" 2016, t. 20/B.

Wykonywanie wyroków Europejskiego Trybunału Praw Człowieka przez Sejm, Biuro Analiz Sejmowych, Warszawa 2012.

Zaleśny J., Zasady prawidtowej legislacji, „Studia Politologiczne” 2009, nr 13.

Zapewnienie efektywności orzeczeń sądów międzynarodowych w polskim porządku prawnym, red. A. Wróbel, Wolters Kluwer Polska, Warszawa 2011.

Żak M., Soft law jako instrument koordynacji regulacyjnej good governance, „Przegląd Legislacyjny" 2019, nr 1(107). 